\title{
Exceptionally preserved nauplius larvae from the Devonian Windyfield chert, Rhynie, Aberdeenshire, Scotland
}

\author{
Carolin Haug, Joachim T. Haug, Stephen R. Fayers, Nigel H. Trewin, \\ Christopher Castellani, Dieter Waloszek, and Andreas Maas
}

\begin{abstract}
We examined a large number of exceptionally preserved nauplius larvae from the Early Devonian Windyfield chert, Rhynie, NE Scotland, situated $600 \mathrm{~m}$ from the famous Rhynie chert lagerstätte locality. Two of the specimens have already been mentioned briefly in an earlier description of Windyfield material, presumed to belong to anostracan crustaceans. From the 79 specimens at hand image stacks were recorded with up to 302 single images of each specimen using a transmitted light microscope. Subsequently, the stacks were projected to obtain stereo images of each specimen. Morphometric analysis made in order to detect possible growth stages revealed three different clusters. These may represent size classes, but we could not recognize any differences in the number of appendage elements, setae, or similar structures between representatives of the different size classes. The eucrustacean nature of the larvae is confirmed, but the new data do not hint at anostracan affinities. In light of their special appendage morphology, particularly the possession of biramous mandibles, the larvae do not even appear to be eubranchiopods, which have a mandible lacking the outer ramus, the exopod. Possibly the larvae belong to a species, which was derived from below the evolutionary level of Eubranchiopoda, but maxillopod affinities are also possible and equally supported from the morphological data. More precisely the species might be a representative of the thecostracan lineage, but the ephemeral freshwater depositional environment and continental palaeogeography do not support this interpretation given that all living representatives of Thecostraca are marine.
\end{abstract}

Carolin Haug. Department of Geology and Geophysics, Yale University, Kline Geology Laboratory, 210 Whitney Avenue, New Haven, 06511 CT, USA

Current address: Zoological Institute and Museum, Cytology and Evolutionary Biology, University of Greifswald, Soldmannstr. 23, 17487 Greifswald, Germany

Joachim T. Haug. Department of Geology and Geophysics, Yale University, Kline Geology Laboratory, 210 Whitney Avenue, New Haven, 06511 CT, USA

Current address: Zoological Institute and Museum, Cytology and Evolutionary Biology, University of Greifswald, Soldmannstr. 23, 17487 Greifswald, Germany

Stephen R. Fayers. Department of Geology and Petroleum Geology, School of Geosciences, University of

PE Article Number: 15.2.24A

Copyright: Palaeontological Association August 2012

Submission: 21 December 2011. Acceptance: 26 July 2012

Haug, Carolin, Haug, Joachim T., Fayers, Stephen R., Trewin, Nigel H., Castellani, Christopher, Waloszek, Dieter and Maas, Andreas. 2012. Exceptionally preserved nauplius larvae from the Devonian Windyfield chert, Rhynie, Aberdeenshire, Scotland. Palaeontologia Electronica Vol. 15, Issue 2;24A,42p;

palaeo-electronica.org/content/2012-issue-2-articles/287-nauplius-larva-in-chert 
Aberdeen, Meston Building, Kings College, Aberdeen, AB24 3UE, UK

Nigel H. Trewin. Department of Geology and Petroleum Geology, School of Geosciences, University of Aberdeen, Meston Building, Kings College, Aberdeen, AB24 3UE, UK

Christopher Castellani. Biosystematic Documentation, University of Ulm, Helmholtzstrasse 20, D-89081

Ulm, Germany

Dieter Waloszek. Biosystematic Documentation, University of Ulm, Helmholtzstrasse 20, D-89081 Ulm, Germany

Andreas Maas. Biosystematic Documentation, University of Ulm, Helmholtzstrasse 20, D-89081 Ulm, Germany

Keywords: Eucrustacea; fossil; ontogeny; Branchiopoda; Maxillopoda; 3D model

\section{INTRODUCTION}

The fossil record of confidently identified nauplii, tiny eucrustacean larvae with only three pairs of functional appendages (antennulae, antennae, and mandibles), is extremely sparse. Apart from some drastic misinterpretations (see discussion), fossil nauplii are, up to now, limited to middle Cambrian to Lower Ordovician 'Orsten'-type deposits (see Maas et al., 2006 for more information on that kind of preservation). The branchiopod Rehbachiella kinnekullensis Müller, 1983 from 'Orsten' limestone nodules from Sweden is the eucrustacean fossil species with the most precisely known ontogenetic sequence (Walossek, 1993). The first four of its 30 described ontogenetic stages are a nauplius (often named 'orthonauplius') and three metanaupliar stages, the latter possessing progressively more rudimentary appendages behind the first three developed naupliar limbs. Another species from the 'Orsten' with a well-preserved ontogenetic sequence including early larval stages is the thecostracan Bredocaris admirabilis Müller, 1983 (Müller and Walossek, 1988). Here, five metanaupliar stages are followed by a stage interpreted as the adult. Early stages are also known from the entomostracan Walossekia quinquespinosa Müller, 1983. The youngest known stage is a metanauplius, but the sequence has not yet been described in detail.

Beside such (more or less) complete developmental sequences, isolated larval stages are also known from the 'Orsten', for which further developmental data including those of the adult are lacking. For example, Zhang and co-authors have described the oldest fossil metanauplius found to date (Zhang et al., 2010). This recently described lower Cambrian larva from China (Wujicaris muelleri Zhang et al. , 2010) shares certain features with extant maxillopodan larvae and is a eucrusta- cean metanauplius. Other examples are the socalled type A larvae, which are apparently orthonauplii, but their eucrustacean affinities have not yet been exactly determined. They possibly represent larvae of more than a single species. Type A larvae are known from both explored layers of the Swedish 'Orsten', ranging from Cambrian Series 3 to late Furongian (Maas et al., 2006), and also from the middle Cambrian of Australia (Walossek et al., 1993), and from the early Ordovician of Newfoundland (Roy and Fåhræus, 1989). Type A larvae can be differentiated into type A1 (Müller and Walossek, 1986) and type A2 larvae. A1 larvae are characterised by three pairs of dorsal humps; these are absent in type A2 larvae. Additionally, caudal spine-like outgrowths of A1 larvae are larger than those of A2 larvae (Walossek and Müller, 1989). Furthermore, a single specimen of a type B larva was described by Müller and Walossek (1986) as representing a possible nauplius.

Lastly, there might be early larvae among the finds of fossil ostracods. The first larval stage, termed A-8 (A minus 8) in species with eight stages (possibly the ground-pattern state; some ingroups have fewer) is interpreted as an orthonauplius and the succeeding stages as metanauplii (cf. Hartmann, 1967). For a number of fossil ostracod species probably complete ontogenetic sequences with eight sub-adult stages down to the earliest instar are known (e.g., Cooper, 1945; Adamczak, 1958). Therefore, the fossil $A-8$ and $A-7$ stages probably also represent nauplii or early metanauplii. However, there are no soft parts preserved hinting to naupliar identity in the material of these early ontogenetic stages, only in rare cases parts of the soft-part anatomy are known, but only from later stages (e.g., Gramann, 1962; Weitschat, 1983; Braun, 1997; Smith, 2000; Williams et al., 2008; review in Becker, 2005). An uncertainty 
arises from the ontogeny of the fossil ostracod Beyrichia jonesi Boll, 1856 reported to have 11 stages (Spjeldnæs, 1951). Therefore, it remains difficult to verify the presence of true nauplii of fossil ostracodes without soft-part preservation.

In this study we describe in detail nauplii from the Early Devonian Windyfield chert, Aberdeenshire, Scotland, of which two of the specimens have been briefly presented before (Fayers and Trewin, 2004; Haug J.T. et al., 2009b). An attempt to describe them in more detail had already been undertaken, but was not published (Fayers, 2003). The Rhynie and Windyfield cherts were formed in a restricted area of hydrothermal hot-spring activity at the faulted margin of the Rhynie Basin, a small strike-slip intercontinental basin (Rice and Ashcroft, 2004). The hydrothermal activity is confined to a small area about $1 \mathrm{~km}$ long and a few $100 \mathrm{~m}$ wide. Trenching and cored drilling (Rice et al., 2002; Trewin and Wilson, 2004) shows that the cherts occur within a sequence of sandstones and shales of fluvial to lacustrine origin. The fauna and flora of both the Rhynie and Windyfield cherts comprise seven species of terrestrial plants, together with terrestrial arthropods (e.g., trigonotarbids, centipedes, mites, see Anderson and Trewin, 2003). Aquatic elements are Palaeonitella cranii (Kidston and Lang, 1921) (charophyte algae, see Kelman et al., 2004), microbial mats, and crustaceans (e.g., Lepidocaris rhyniensis, Castracollis willsonae, see Fayers and Trewin, 2004).

While the first arthropods from the Rhynie chert were described in the 1920s (for a summary on the history of research of the Rhynie area see Trewin, 2004), the Windyfield chert with its biota was only discovered in situ in 1997 (reviewed in Fayers and Trewin, 2004). Crustaceans are to date represented only by branchiopods (Anderson and Trewin, 2003; Fayers and Trewin, 2004). Therefore, one aim of this work was to describe the morphology of the nauplii from the Windyfield chert in detail and, based on this, to evaluate their phylogenetic placement. The findings reported here are the only confidently known post-Ordovician records of fossil nauplii, and also the only record of such fossil larvae from a non-marine environment.

\section{MATERIAL AND METHODS}

\section{Material}

The examined specimens are preserved in chert samples from the Windyfield locality, Rhynie, Aberdeenshire, Scotland. The stratigraphic age is Pragian-earliest Emsian based on spores (Well- man, 2006). A radiometric ${ }^{40} \mathrm{Ar} / 39 \mathrm{Ar}$ age of $403.9 \pm$ 2.1 Ma has been obtained by Mark et al. (2011) on $\mathrm{K}$-feldspar from a quartz-feldspar vein that is part of the hydrothermal system that was responsible for the formation of the Rhynie cherts. This Ar/Ar age converts to $407.1 \pm 2.2 \mathrm{Ma}$ on the U/Pb timescale. Parry et al. (2011) dated zircon and titanite from hydrothermally altered andesite and obtained a U/Pb age of $411 \pm 1.3 \mathrm{Ma}$. The andesite cannot be fixed with certainty in the stratigraphic sequence and is certainly older than the hydrothermal alteration. Both dates are useful, but that of Mark et al. (2011) is more likely to give the age of the hydrothermal system and hence the age of the Rhynie cherts.

The chert was cut into thin slices and these were polished on both sides and glued on unfrosted glass slides for studying with a light microscope (see below). The investigation included nine thin sections containing 79 specimens, most of them being fragments representing single legs or leg assemblages; only in rare cases are whole animals preserved. The micro slides have been assigned to the collection numbers AUGD 12442, 12444, 12445, 12447, 12448, $12449,12451,12452$ and 12454 , all housed in the Type and Figured collections of the Department of Geology and Petroleum Geology, University of Aberdeen. Overview images of the complete slides with the position of all specimens marked on the slides are attached in the appendix (Appendices 1 , 2, 3, 4, 5, 6, 7, 8, 9, 10). Specimen AUGD 12448A has been depicted in Fayers and Trewin (2004, figure 8B) and specimen AUGD 12449B in Haug J.T. et al. (2009b, figures 1, 3).

\section{Transmitted-light microscopy}

The specimens were studied using a Zeiss Axioskop 2 and imaged using an AxioCam digital camera. Objectives used were either of $10 \times$ or of 20x magnification, which together with the camera magnification resulted in magnifications of about $100 \times$ or $200 \times$.

Specimens were viewed both through the glass slide on which the chert slice was mounted, and also from the unmounted face of the slice using immersion oil and a glass coverslip. As the fossils extend to a certain depth into the matrix, a stack of single images (= frames) was recorded for each specimen, the first frame at a level slightly above the specimen and the last frame at a level slightly below it. The camera then recorded a frame every $1 \mu \mathrm{m}$ in $\mathrm{z}$-axis, resulting in image stacks of up to 302 single frames. 


\section{Computer processing}

A combination of freely available software packages was applied to optimally use the positional information of the body parts of the specimen in the image stack, i.e., to understand the morphology in three dimensions. The 3D-approach is necessary, as single 2D-images do not provide enough information to sufficiently understand the morphology of the specimens enclosed in the chert. This is especially true as the depth of field within the chert is highly limited.

ImageJ was used to find the sharp edges in each frame of the stack, i.e., the structures in focus in the frames became white, while blurred areas became black. The processed image stack was then projected in three dimensions from which stereo images were produced with OsiriX (for a detailed methodological description, see Haug J.T. et al., 2009b). This method was only applied to the best specimens in the material (see below).

In cases where the specimen was rather deep in the chert or the surrounding matrix was very coarse, the 'find edges' function of ImageJ did not yield satisfying results, as the dirt particles became pronounced and concealed details of the specimen. In these cases ImageJ was at first used to calculate a (plain) minimum intensity projection. This means that all pixels at the same $x$-y-position within the image stack are compared and the darkest ones are put together into one compound image. This type of compound image, thus, projects the highly contrasted structures into one image, giving a good overview, but dampening the details especially in the less contrasted specimens. These projections do not provide as detailed morphological information as do the 3D projections but measurements are usually more easily taken from the minimum intensity projections (see "Measurements").

In a second step a related method was applied to produce a three-dimensional projection for those specimens for which the method of Haug J.T. et al. (2009b) did not provide satisfactory results. All frames of a stack were inverted so that structures appeared in white to light grey, while the background became black to dark grey. These stacks were loaded into OsiriX and projected as a maximum intensity projection in three dimensions, comparable to the method described by Haug J.T. et al. (2009b). From these projections stereo images were taken, and further processed in the freely available image processing software Gimp 2.6 or in Adobe Photoshop CS3, mainly with the 'unsharp mask' sharpening tool to enhance structures. Stereo images of this projection type are presented for all specimens in this publication to provide the reader with all the image information obtained from the material; the application of the same computer processing allows direct comparability of all specimens.

Compared to the method described by Haug J.T. et al. (2009b) the images projected with the afore-described method appear more "cloudy", but there are also fewer dirt particles visible (see below). Unfortunately, but unavoidably, fine details such as setules are also much less apparent. Both methods are seen to have their advantages and are used in parallel.

\section{Measurements}

Measurements of the specimens were obtained either on the stereo images or on the plain minimum/maximum intensity projections, depending on where the structures could be detected more easily. If both views could not provide sufficient information, the measurements were conducted via the image stacks directly. For that purpose it was necessary to focus through the different levels using ImageJ to detect the measurable structures. For calibration a microscopic scale was used.

The maximum body width was usually measured on the cephalic shield. If the shield outline was not available (for growth stage I, see below), the distance between the proximo-lateral edge of an appendage on one side to that of the corresponding appendage on the other side was measured.

As the exopods of antennae and/or mandibles were present on many specimens, their maximum diameter at the most proximal part was measured (Figure 1). The circular cross section of the exopods made it possible to achieve reliable results regardless of their orientation in the slide.

Additionally, the maximum diameter of the endopods of antennae and mandibles was measured. On the antennae this could be detected at the second most proximal element of the endopod, on the mandible it was the most proximal part of the very small endopod (Figure 1). Furthermore, the maximum length and height of the coxae of the antennae was specified (Figure 1), but taking only coxae in parallel orientation to the section plane. The coxae of the mandibles were not exposed well enough to acquire any data. 
ant

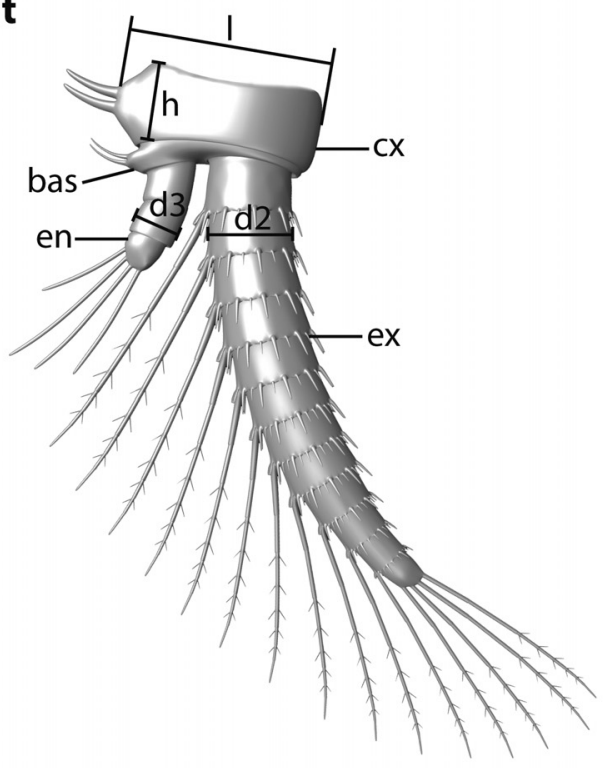

md

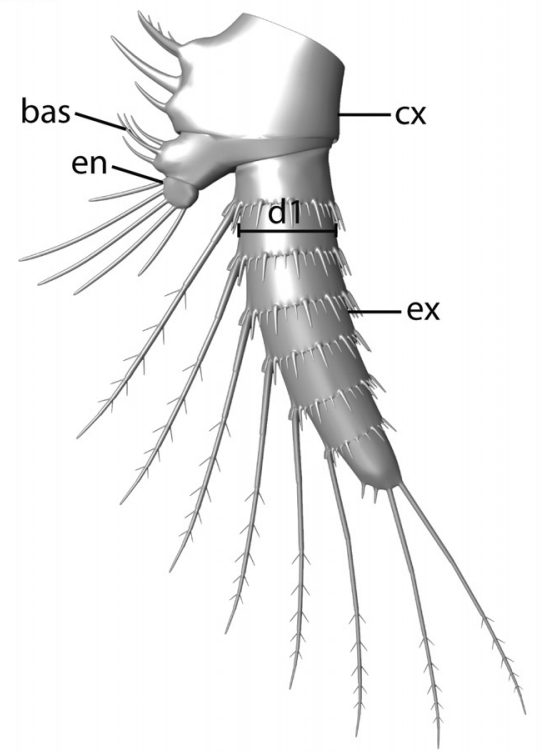

FIGURE 1. Scheme depicting the measured parts of antenna (ant) and mandible (md): $d 1=$ diameter of the mandibular exopod (ex); d2 = diameter of the antennal exopod; $d 3=$ diameter of the antennal endopod (en); $h=$ height of the antennal coxa (cx) in proximal-distal axis; I = length of the antennal coxa in median-lateral axis. Other abbreviation: bas $=$ basipod .

\section{Statistical methods}

Several distances were plotted versus each other to search for occurrence of cluster formation of size classes. Plotted graphs (Figure 2; see Figure 1 for orientation) document the:

- diameter of the exopod of the mandible (d1) versus the diameter of the exopod of the second antenna (d2) (Figure 2.1);

- diameter of the endopod of the second antenna (d3) versus the diameter of the exopod of the second antenna (d2) (Figure 2.2);

- height of the coxa of the second antenna in proximal-distal axis $(h)$ versus the length of the coxa of the second antenna in medianlateral axis (I) (Figure 2.3);

- diameter of the exopod of the second antenna (d2) versus the length of the coxa of the second antenna in median-lateral axis (I) (Figure 2.4).

To test the hypothesis that there are different size classes, a statistical analysis was run. 23 specimens, which exhibited the same three measurable parameters $(d 2, d 3, I)$, were included. The Shapiro-Wilk test revealed that the data sets were normally distributed $(p>0.05)$. Therefore, para- metric tests were chosen for the statistical analyses. The data were plotted on a 3D graph for observing morphological differences (Figure 2.5). A boxplot was used to illustrate the variability of each group concerning d2 (Figure 2.6). The group identification was tested with a Multivariate Analysis of Variance (MANOVA), and an a posteriori Scheffe test was applied to specify the nature of differences between each group.

As the antennulae were only visible in two specimens, they were not used for any statistical analysis, but their maximum diameter was included in the description and reconstruction. The same problem arose with the labrum and the shield, so their maximum visible lengths were also measured just for descriptive purposes. The total lengths of the appendages and the lengths of single leg elements as well as the complete sizes of the specimens could not be measured accurately because of their disadvantageous orientation in the chert. Therefore, these values had to be estimated for the description and the reconstruction.

On the one hand, taphonomic constraints such as coarse texture and inclusions within the chert, or the disarticulation of the animals into single legs, which are then often coiled around each other, complicated measurements of lengths or widths and the counting of setae. On the other 

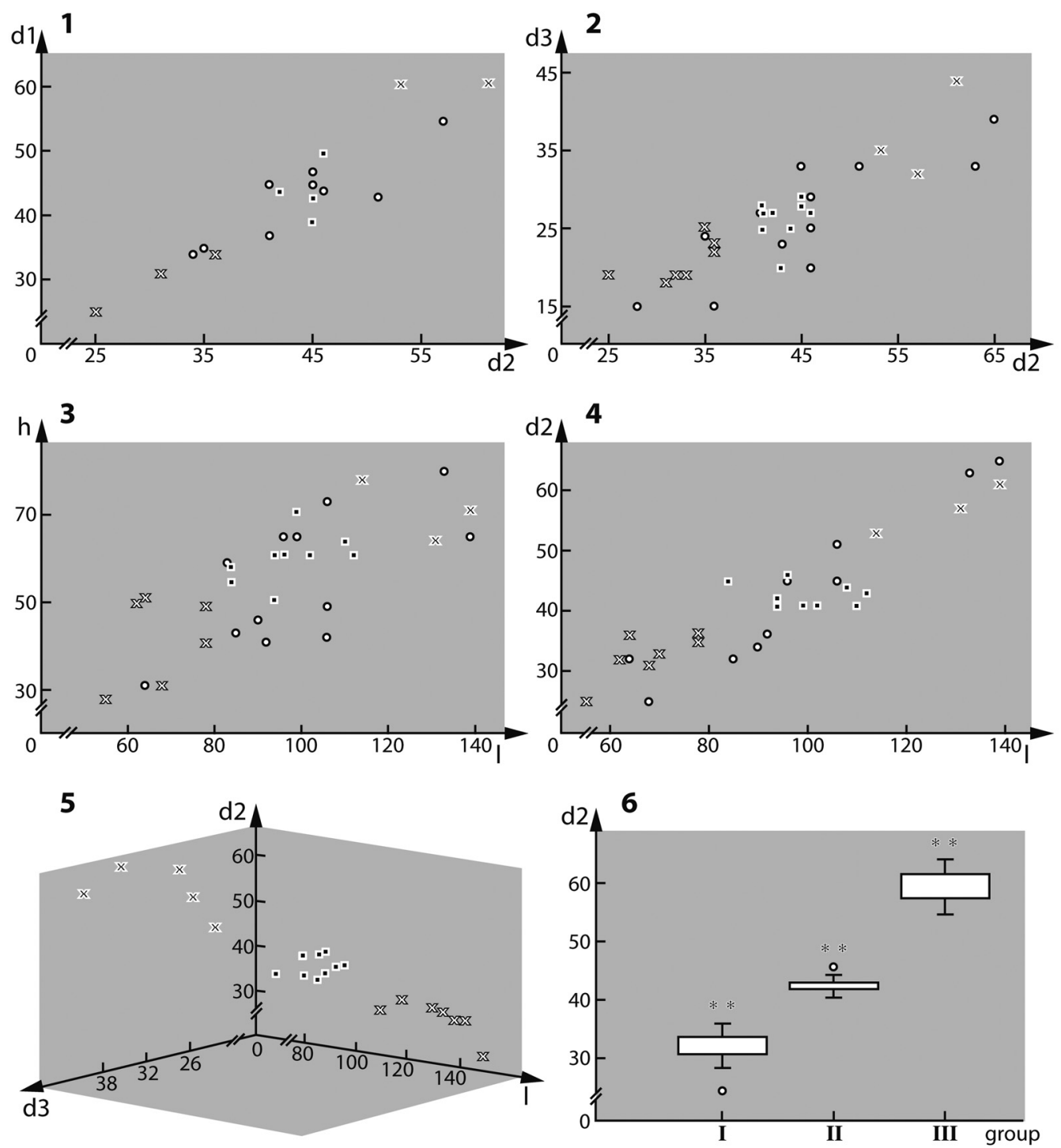

FIGURE 2. Scatter and box plots of the measured parameters. 2.1. Diameter of the mandibular exopod (d1) versus diameter of the antennal exopod (d2). 2.2. Diameter of the antennal endopod (d3) versus diameter of the antennal exopod (d2). 2.3. Height of the antennal coxa in proximal-distal axis (h) versus length of the antennal coxa in medianlateral axis (I). 2.4. Diameter of the antennal exopod (d2) versus length of the antennal coxa in median-lateral axis (I). 2.5. 3D scatter plot of specimens of which $d 2$, d3 and I could be measured. 2.6. Box plot of parameter d2; three size classes highly significant (Wilks Lambda $=0.097, \mathrm{~F}=12.505, \mathrm{p}<0.0001$ ).

hand, intraspecific variation as occurs in some arthropods might make measurements difficult to fix, e.g., the number of setae or pattern of setation. Therefore, in the reconstruction (see below) an "average animal" was chosen, with lengths that appeared to be the most reliable ones.

\section{D model}

For the restoration of the principle morphology by means of a three-dimensional model, the freely available software Blender was used. Based on data of many specimens, an "average larva" was developed. This was only facilitated by the fact that no apparent morphogenetic changes could be detected between the specimens besides isometric growth (see below).

\section{RESULTS}

\section{Preservation}

Preservation varies significantly between the specimens. To illustrate this, we present here 


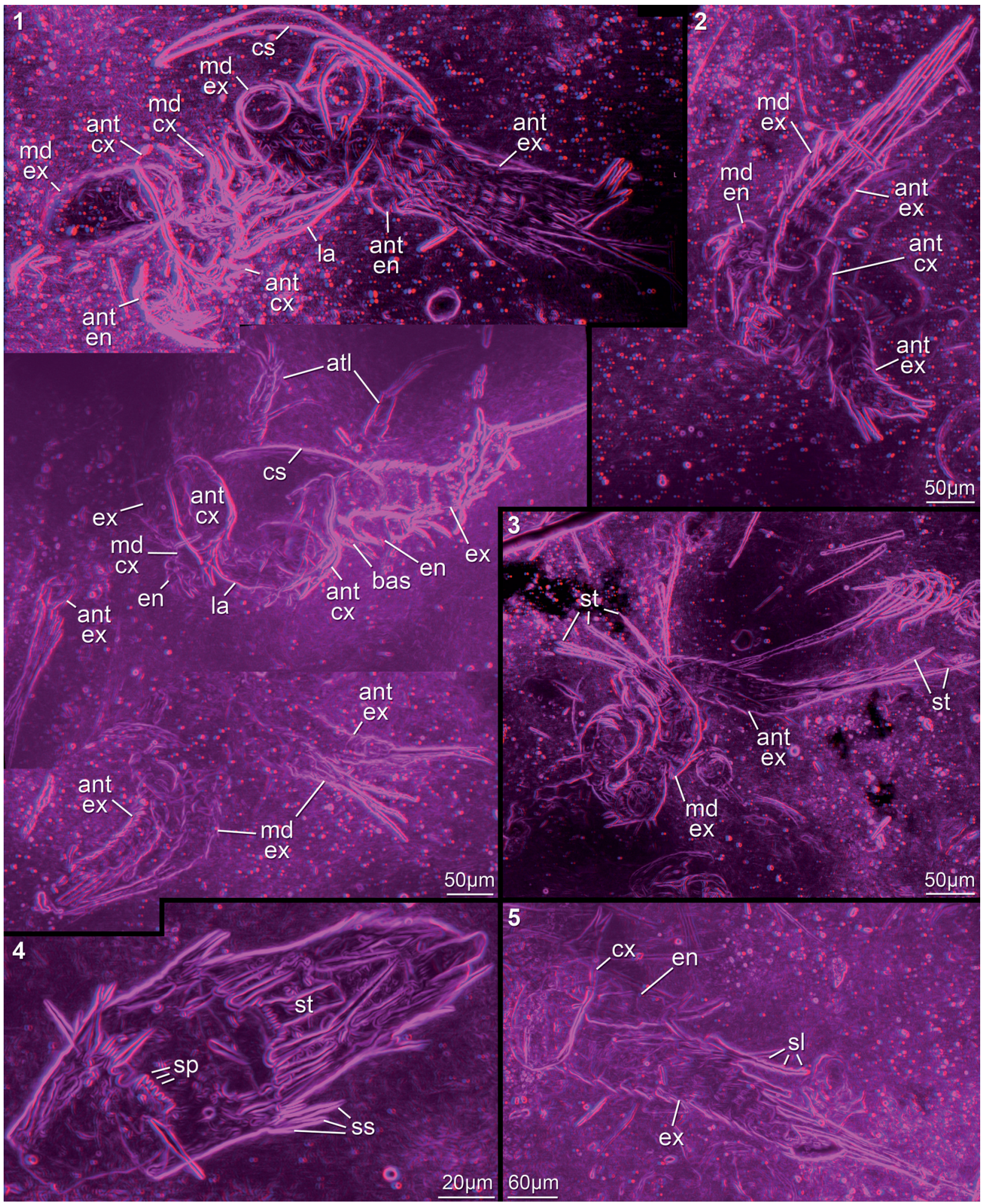

FIGURE 3. Red-blue stereo images of very well preserved specimens processed after the method of Haug J.T. et al. (2009b). 3.1. Best preserved specimens of size class III (top; collection number AUGD 12449B [AUGD omitted in the following]), II (middle; 12448A), and I (bottom; 12449E) respectively; all three specimens to the same scale. 3.2. 12449C. 3.3. 12449A02. 3.4. 12449A10. 3.5. 12449A04. Abbreviations: atl = antennula; $c s=$ cephalic shield; la = labrum; sl = setule; $\mathrm{sp}=$ spine; ss = surrounding seta; st = seta. Other abbreviations as before. 


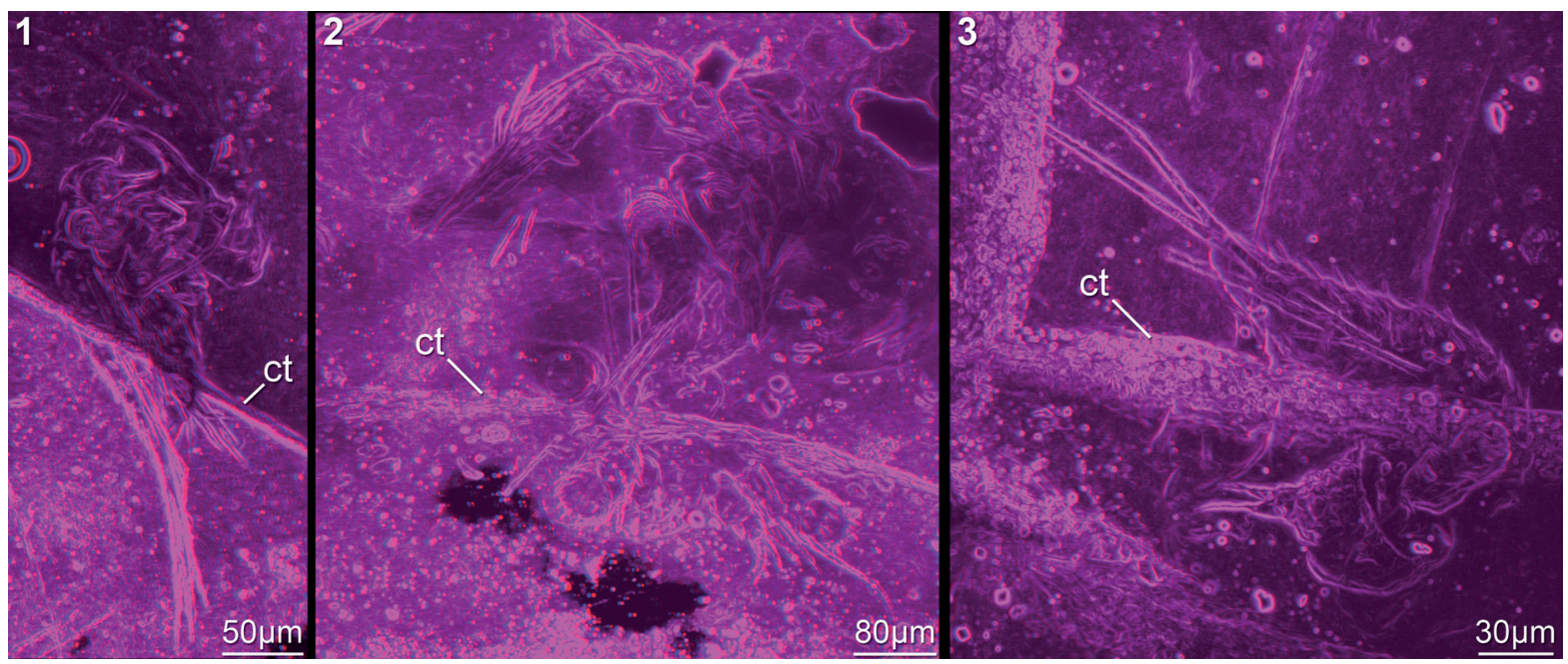

FIGURE 4. Red-blue stereo images of well preserved specimens processed after the method of Haug J.T. et al. (2009b). This method is disadvantageous here, as strongly contrasted areas of the matrix, so-called "curtains" (ct), appear to cut the animal into two halves. 4.1. 12449A25. 4.2. 12449A05. 4.3. 12449A08.

images of all 79 specimens. Some specimens are extremely well preserved and could be documented in great detail using the method described by Haug J.T. et al. (2009b) (Figure 3), exhibiting even finest details such as setae and setules. Other specimens could not be documented properly with this method, although they show good contrast against the matrix, certain areas of the matrix also show high contrast and appear to cut the animal into two halves (Figure 4). Therefore, all specimens were additionally documented using our new projection method described above (Figures $5,6,7,8,9,10,11,12,13)$. Very well-preserved specimens are fully articulated and exhibit smallest details (Figures 5,6 ), such as very minute setules (e.g., Figure 6.8), but these are less well apparent with the new projection method than with the method described by Haug J.T. et al. (2009b) (compare results of method of Haug J.T. et al., $2009 \mathrm{~b}$ in Figure 3 with those of the new method in Figures 5 and 6). Other specimens seem to be equally well preserved, but rest in a more cloudyappearing matrix (Figure 7) or in one even containing particles or "curtains" (possibly cracks) (Figure 8, particularly Figure 8.1, 8.3). These disturbances prevented a proper application of the method described by Haug J.T. et al. (2009b) (compare Figure 4.3 and Figure 8.3). Some specimens were only fragments representing limbs or parts of them (Figure 9), but often still allowed the recognition of tiny structures such as minute spines (Figure 9.3). Such fragmentary specimens can also be found within cloudier matrix areas (Figure 10). Other also partially articulated specimens are much more weakly preserved (Figure 11), in many cases allowing just the recognition of its affiliation with the investigated species (Figure 12). Faint specimens, which are additionally preserved in very cloudy areas, are recognisable as parts of a nauplius, but do not provide further details (Figure 13).

\section{Measurements}

We can confirm the naupliar status of the specimens in the Windyfield chert thin sections as stated by Fayers and Trewin (2004). There were never more than three pairs of appendages present on any of the specimens, which also implies that these larvae belong to a eucrustacean ingroup. These appendages could clearly be identified as the antennulae, antennae and mandibles because of their morphology (antennulae uniramous and made of few rod-shaped elements, antennae and mandibles biramous with characteristic elements and details, particularly their annulated exopods with one seta on the inner distal edge of each annulus) and their position on the animal in relation to the labrum. There were no hints to the existence of further post-mandibular appendages on the articulated specimens, and there were also no disarticulated fragments within the chert that could represent such appendages.

The different length plots of the specimens (Figure 2) clustered in three groups, pointing to three distinct size classes (Figure 2.1-4). For specimens without sufficient measurable length values, assignment to a certain size class was approxi- 


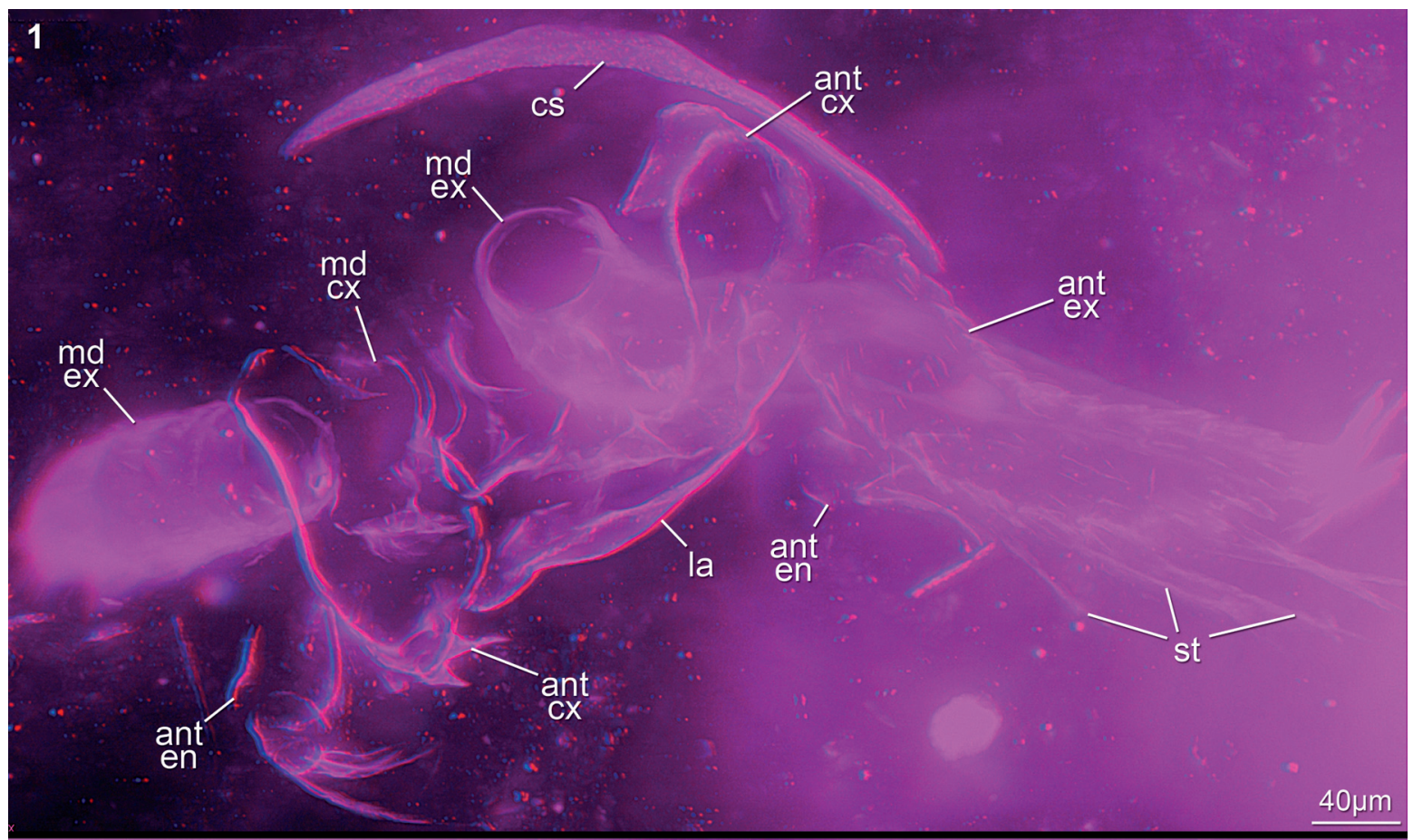

2
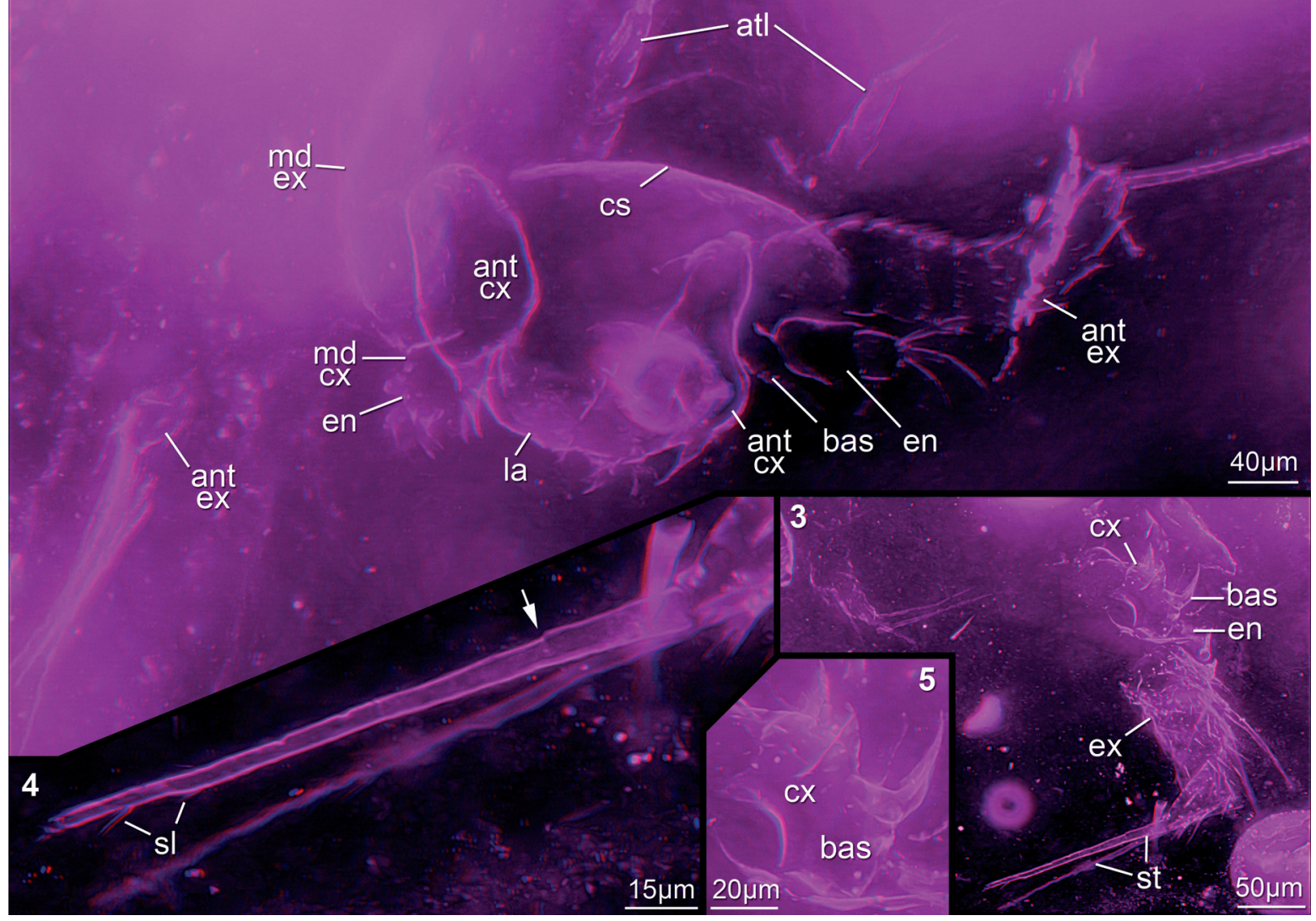

FIGURE 5. Red-blue stereo images of very well preserved specimens. 5.1-2. Rather complete specimens indicating position of appendages in relation to each other. 5.1. 12449B. 5.2. 12448A. 5.3-5. Mandible with many details preserved; 12449A01. 5.3. Entire specimen. 5.4. Terminal setae with setules and visible subdivision (arrow). 5.5. Spines on basipod and coxa. Abbreviations as before. 


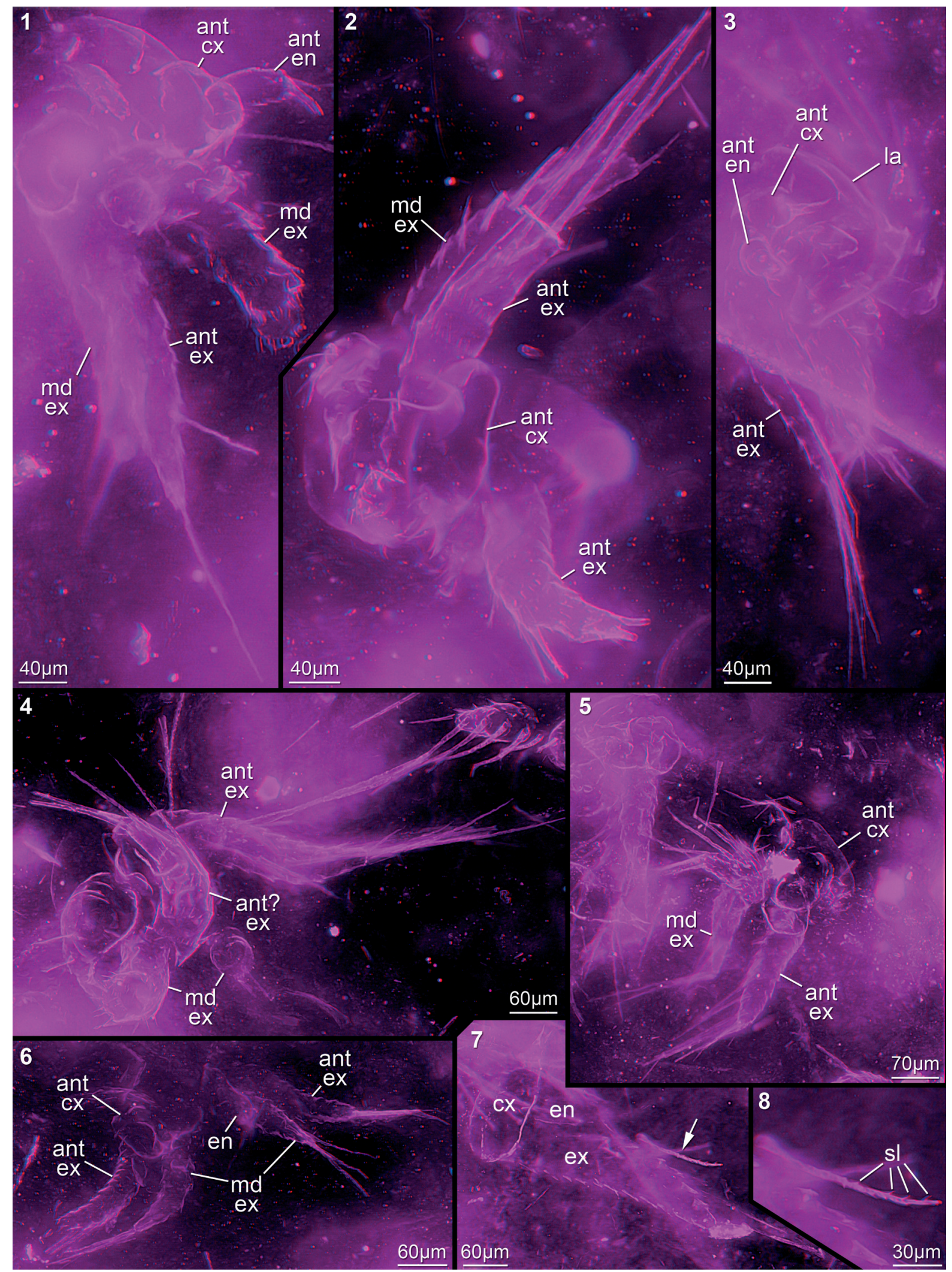

FIGURE 6. Red-blue stereo images of well preserved specimens mainly representing several appendages of one nauplius. 6.1. 12448B. 6.2. 12449C. 6.3. 12449A25. 6.4. 12449A02. 6.5. 12449A03. 6.6. 12449E. 6.7-8. 12449A04. 6.8. Minute setules preserved. Abbreviations as before. 


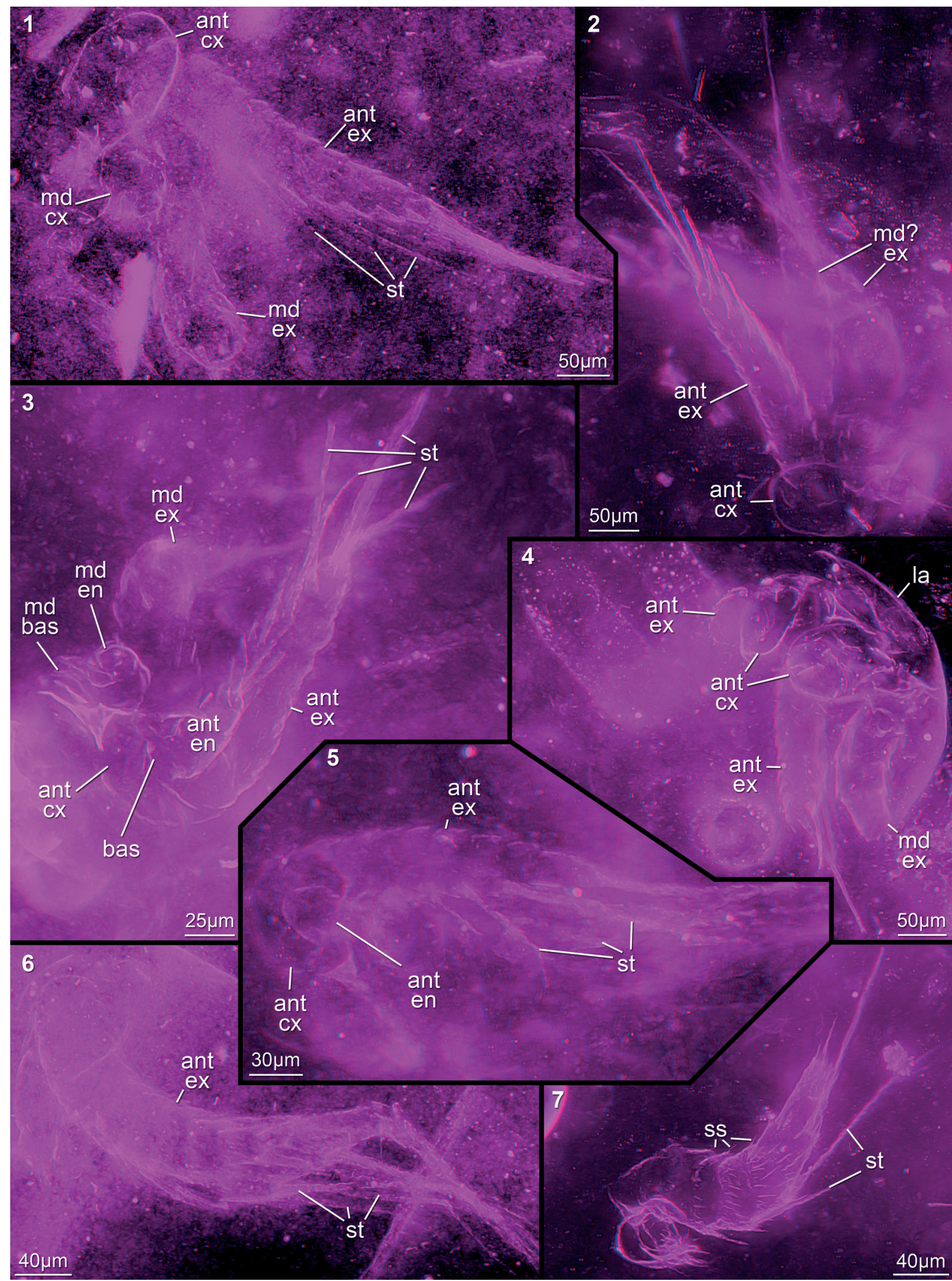

FIGURE 7. Red-blue stereo images of well preserved specimens, but in cloudy-appearing matrix. 7.1. 12445D. 7.2. 12449A20. 7.3. 12449A18. 7.4. 12451F. 7.5. 12447C. 7.6. 12447A. 7.7. 12449A22. Abbreviations as before. 


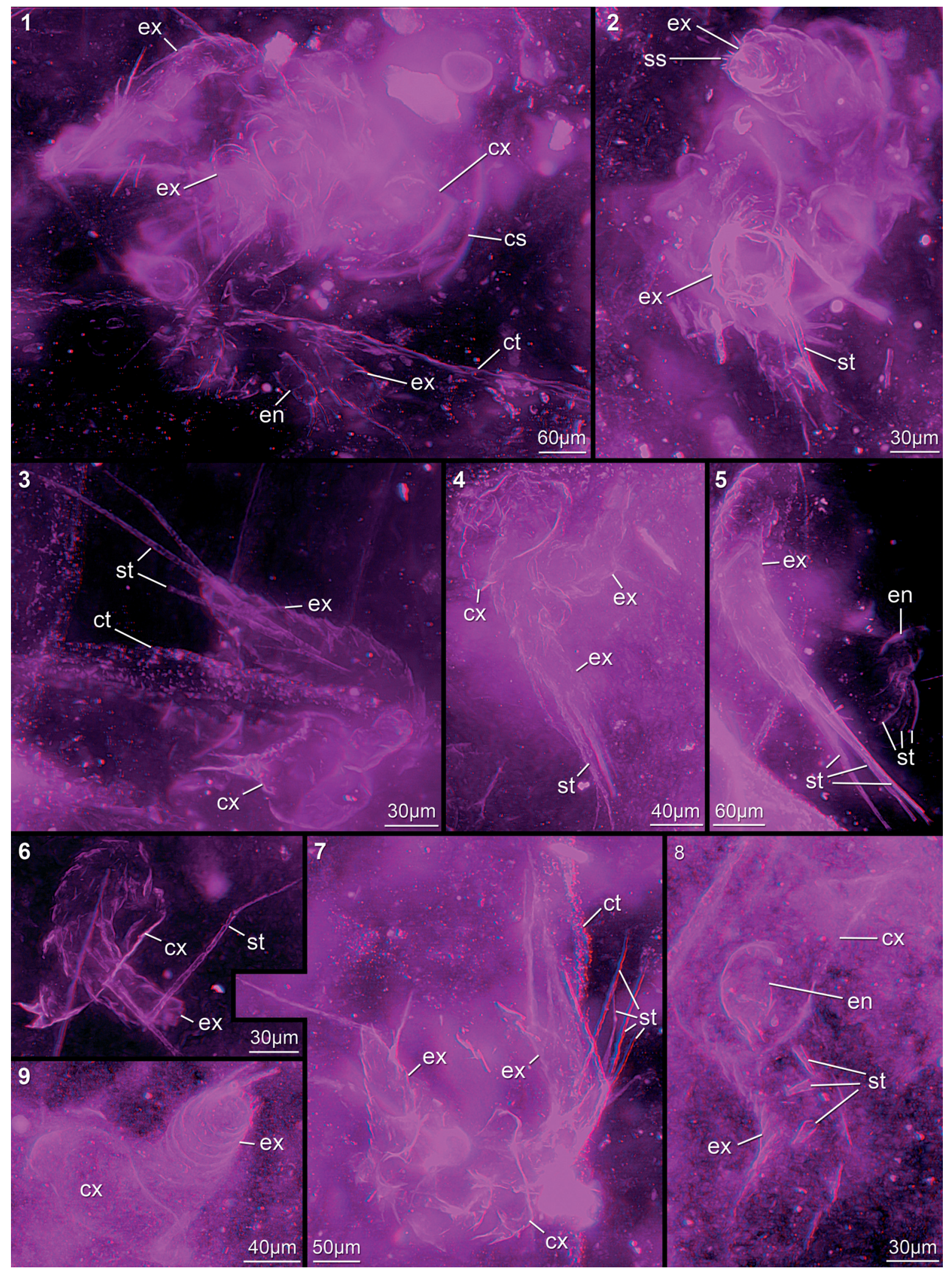

FIGURE 8. Red-blue stereo images of well preserved specimens, but matrix contains many particles or "curtains" (supposedly cracks). 8.1. 12449A05. 8.2. 12449A06. 8.3. 12449A08. 8.4. 12449A16. 8.5. 12449A09. 8.6. 12449A14. 8.7. 12449A19. 8.8. 12447B. 8.9. 12454C. Abbreviations as before. 


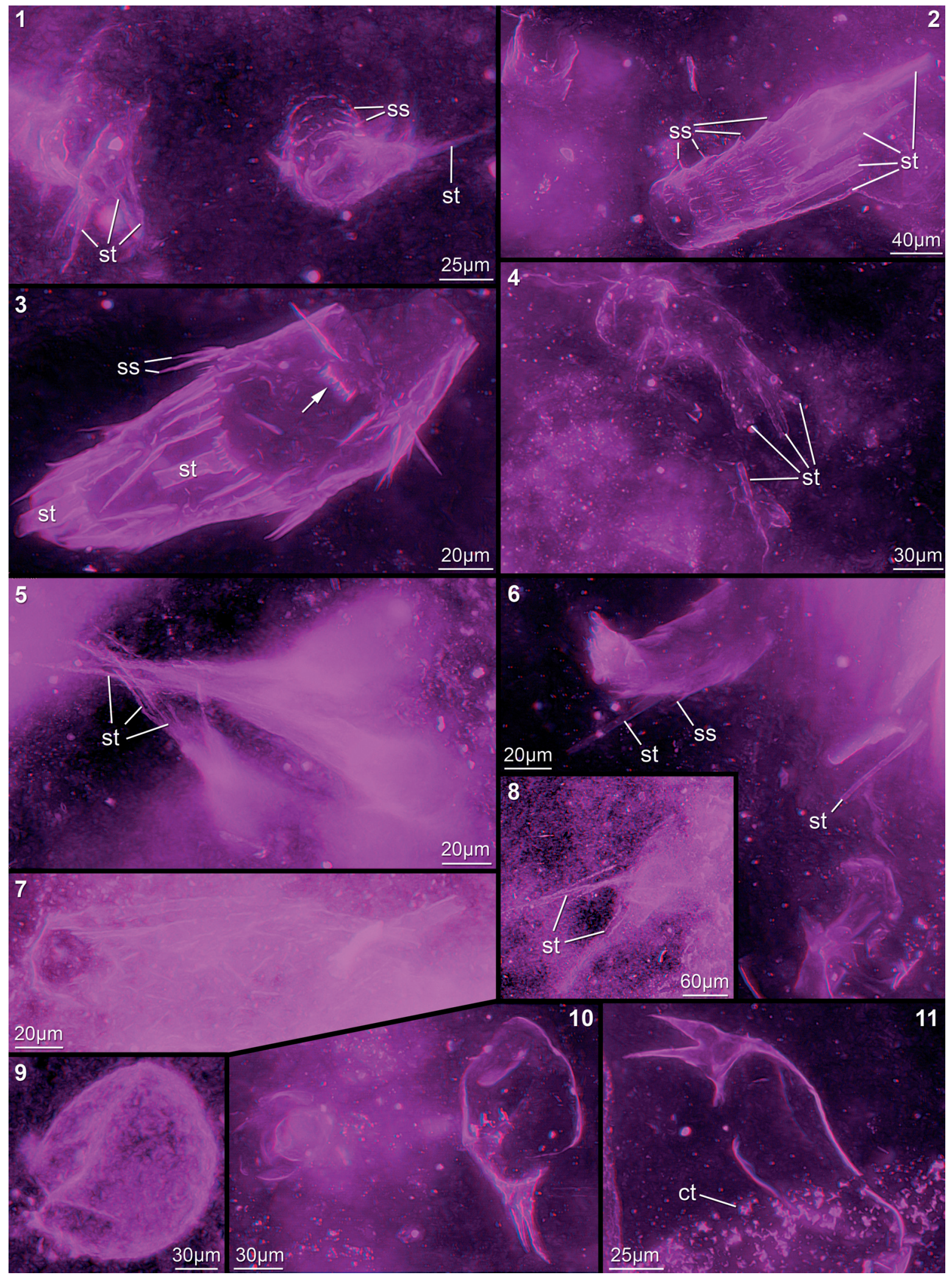

FIGURE 9. Red-blue stereo images of appendage fragments, mainly parts of exopods (9.1-8), but also coxae (9.911). 9.1. 12452B. 9.2. 12449A21. 9.3. 12449A10. 9.4. 12451B. 9.5. 12447F. 9.6. 12449G. 9.7. 12454F. 9.8. 12442E. 9.9. 12454D; supposed coxa in unusual preservation. 9.10. 12451C. 9.11. 12449A15. Abbreviations as before. 


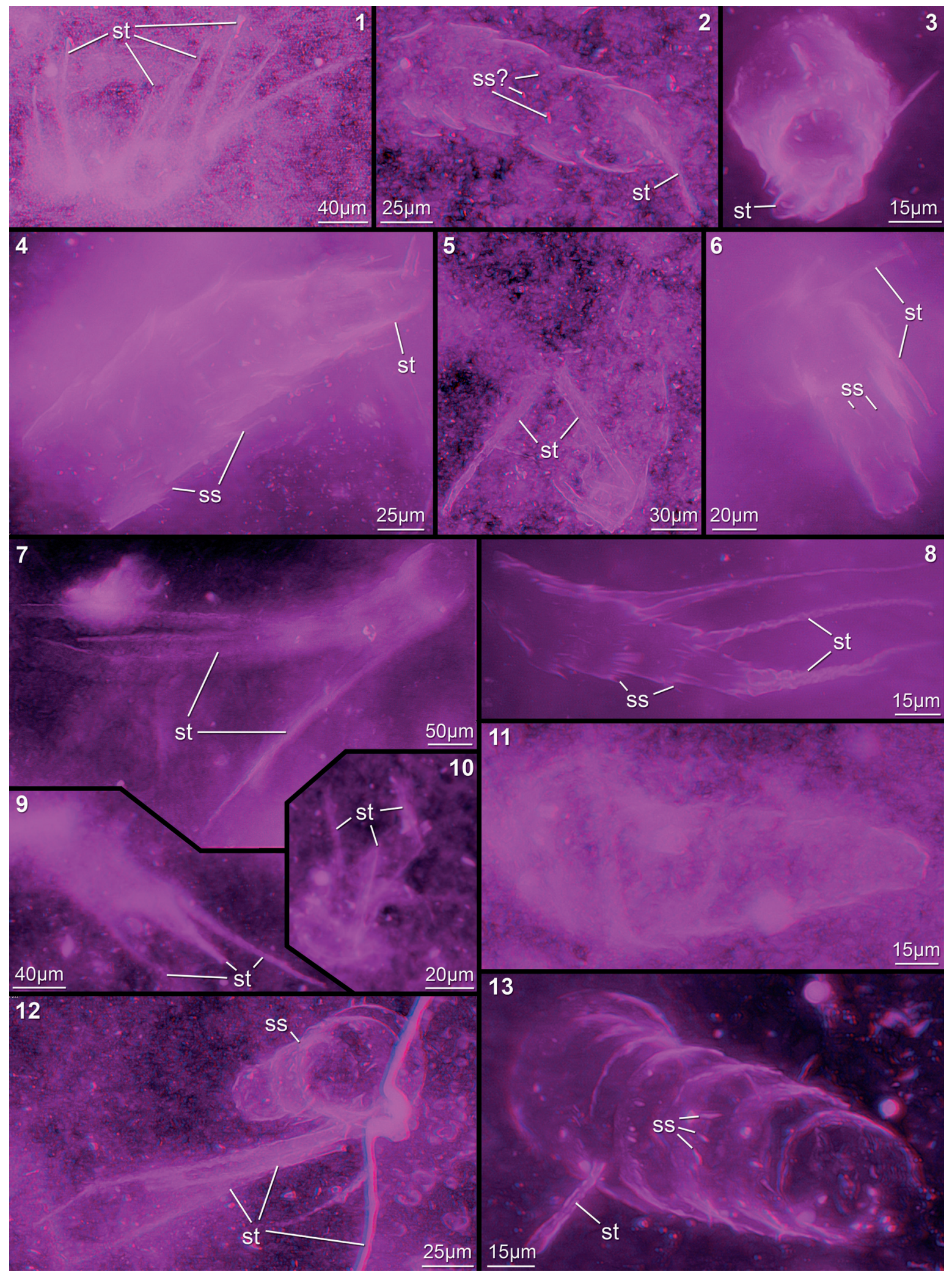

FIGURE 10. Red-blue stereo images of appendage fragments in cloudy-appearing matrix areas, probably all representing exopod fragments. 10.1. 12442B. 10.2. 12445A. 10.3. 12447E. 10.4. 12447D. 10.5. 12444B. 10.6. 12448E. 10.7. 12448F. 10.8. 12449A23. 10.9. 12454G. 10.10. 12454I. 10.11. 12454B. 10.12. 12454H. 10.13. 12451D. Abbreviations as before. 


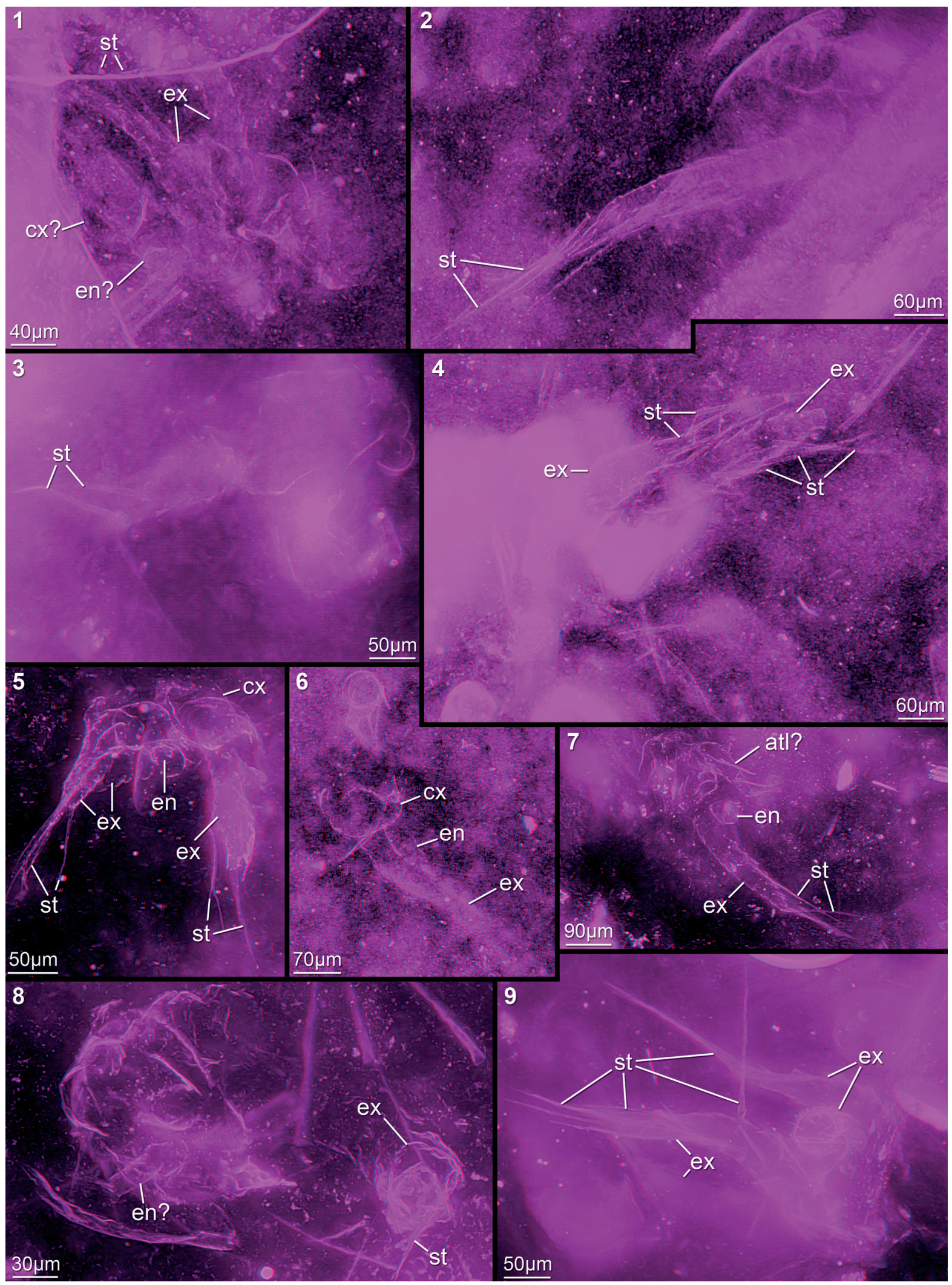

FIGURE 11. Red-blue stereo images of rather faintly preserved specimens, but still several details visible. 11.1. 12454E. 11.2. 12442D. 11.3. 12448G. 11.4. 12454A. 11.5. 12451A. 11.6. 12445F. 11.7. 12449A17. 11.8. 12449A11. 11.9. 12449A07. Abbreviations as before. 


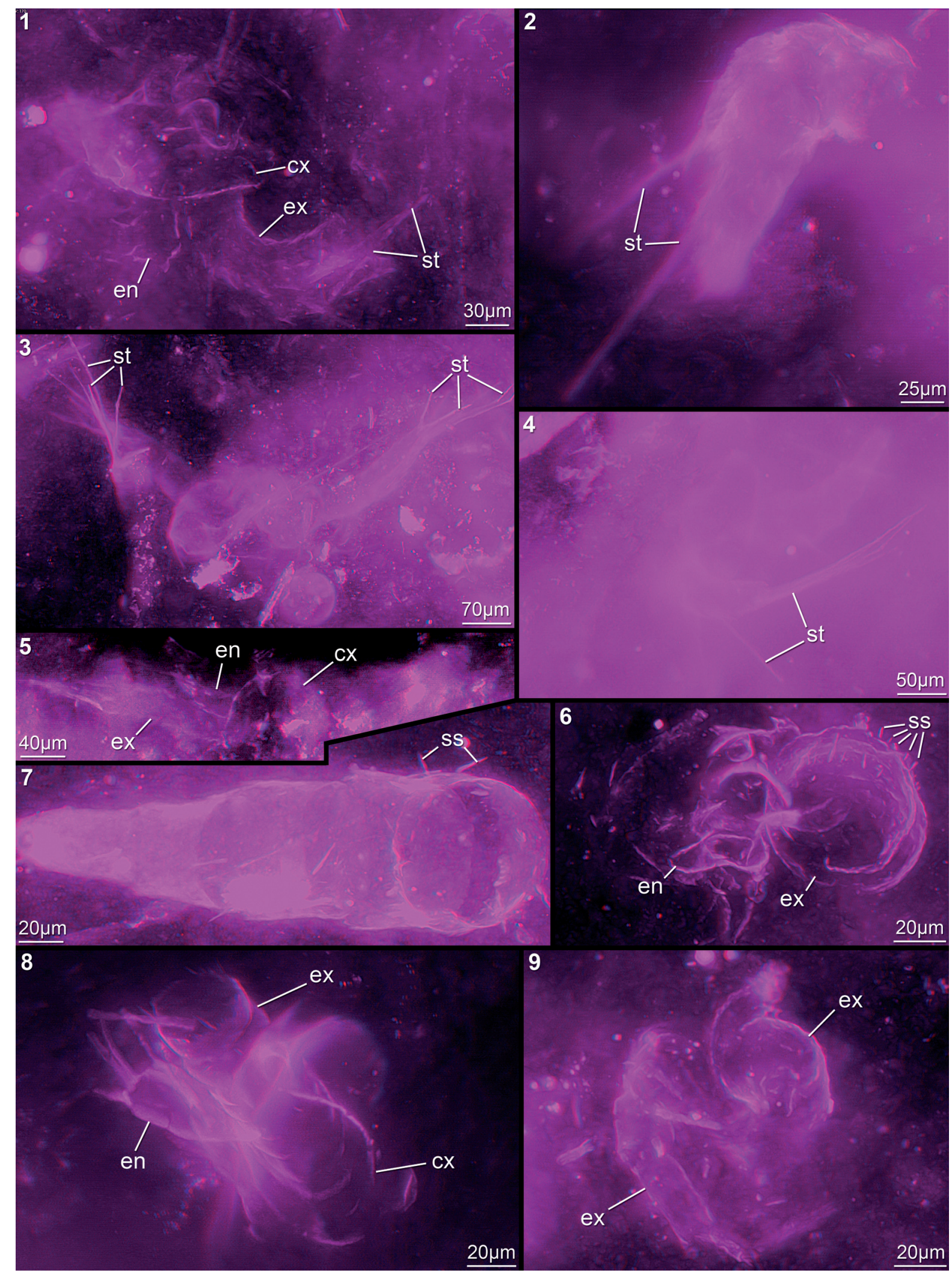

FIGURE 12. Red-blue stereo images of faintly preserved specimens; still assignment to here presented nauplius larvae possible due to preserved details. 12.1. 12451G. 12.2. 12449D. 12.3. 12449A13. 12.4. 12448C. 12.5. 12449F. 12.6. 12449A12. 12.7. 12452A. 12.8. 12449A24. 12.9. 12451E. Abbreviations as before. 


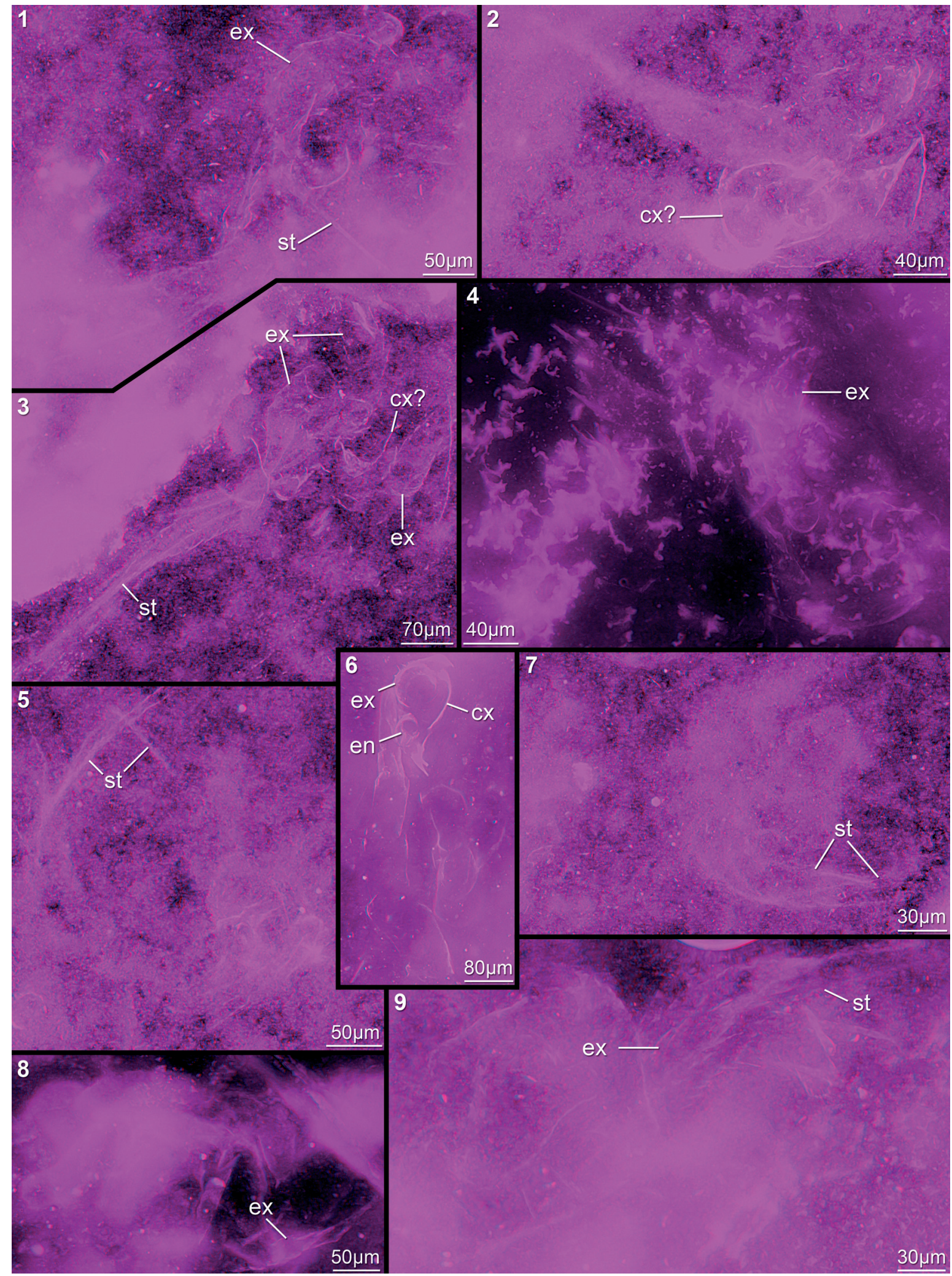

FIGURE 13. Red-blue stereo images of faintly preserved specimens in cloudy-appearing or particle-contaminated matrix areas. 13.1. 12442A. 13.2. 12444A. 13.3. 12442C. 13.4. 12448D. 13.5. 12445E. 13.6. 12448H. 13.7. $12445 \mathrm{~B}$. 13.8. 12447G. 13.9. 12442F. Abbreviations as before. 


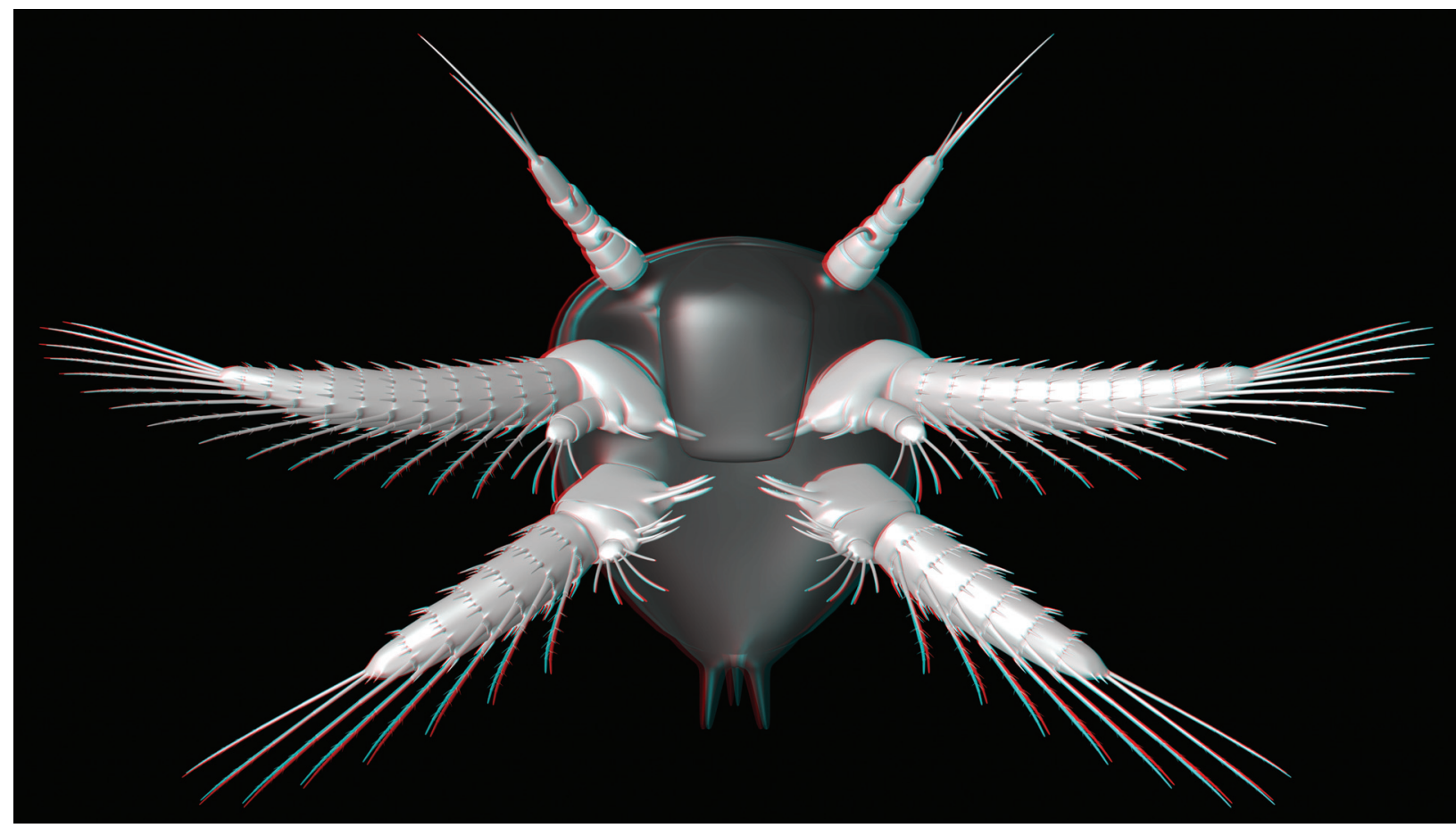

FIGURE 14. Red-cyan stereo image of 3D reconstruction of the here described nauplius in ventral view. Body in dark grey to indicate lacking data.

mated (marked by brackets in Table 1). The subsequent statistical analysis supported the existence of three different size classes (Figure 2.5). In size class I, all three parameters were smaller than in size class II, and those of size class II again smaller than those of size class III. The differences between the size classes were highly significant (Wilks Lambda $=0.097, F=12.505, p<0.0001$ ). The applied a posteriori Scheffe test indicated that the size classes differ from each other in the mean values of each parameter (Figure 2.6 for d2), which led us to accept the hypothesis that three size classes are present in the material.

For the 'Orsten' fossils, which are the ones most comparable to these Windyfield nauplii, it has already been demonstrated that measuring body parts is a valid method for detecting size classes in arthropod fossils (Walossek, 1993; Maas et al., 2003; Stein et al., 2008; Haug J.T. et al., 2009a, $2010 a, b)$. In the present material, size class I contains 20 specimens, size class II 39 specimens, and size class III 11 specimens (see Table 1). For five specimens it has remained unclear whether they belong to either size class II or III; one specimen belongs to either I or II; three specimens could not be assigned to a particular class. Since size increase in Arthropoda is only possible by moulting, these three size classes might be best inter- preted as corresponding to moulting stages, i.e., the clusters correspond to instars. Yet, it must be emphasized that there are no morphological changes detectable in the material besides size increase, so presumably size classes I-III are real successive stages, but without significant morphogenetic change. This habit is in extant eucrustaceans only present in parasitic groups and will be discussed further below.

\section{Description of the morphology of the nauplii}

As we need to describe the morphology of three growth stages (Figure 3.1), lengths are given for each growth stage separately (see Table 2 for an overview of the most important values). This is done in the text in the following manner: growth stage I/II/III. Question marks behind the measured lengths indicate uncertainties due to preservational constraints; dashes mark unavailable data.

Gross morphology. Anterior body margin appears gently rounded. No evidence of the presence of a naupliar eye, but this could be due to suboptimal orientation in the matrix and thin section preparation. Dorsal area forming a cephalic shield (Figures $3.1,5.1-2$ ), as wide as maximum body width and slightly domed, made apparently of thin cuticle without ornamentation. No indications for the presence of a dorsal organ. Ventral side with a wide, 

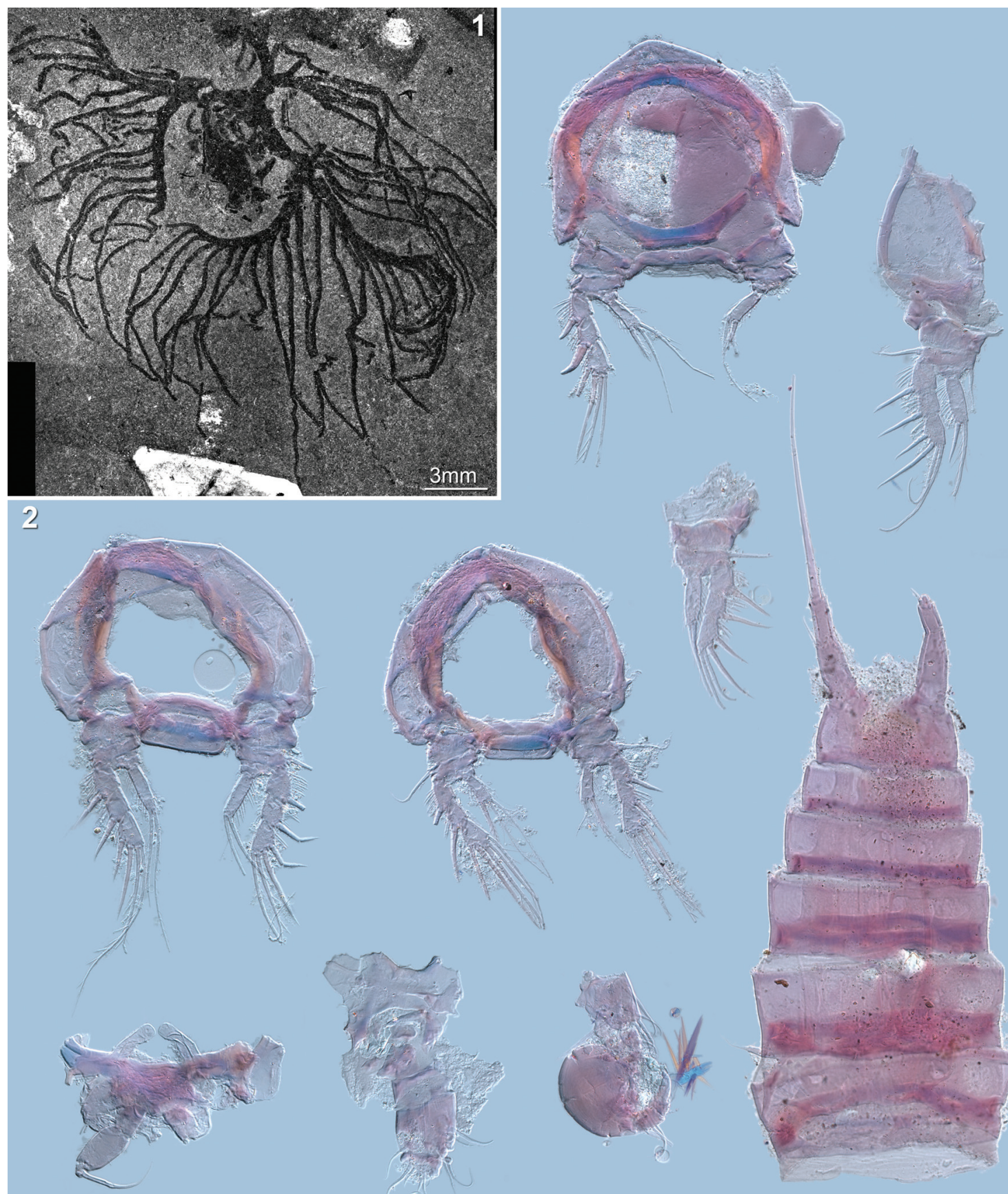
TABLE 1. Measurements for all specimens in micrometers with reference to appearance on certain figures. Brackets indicate uncertainties in assignment to certain size class or in measured values due to weak preservation. Specimen AUGD $12445 \mathrm{C}$ is mentioned, as it was documented and received a number, but later turned out as not being part of a crustacean. Numbers in first row mean: 1 = Figure; 2 = Repository number AUGD; 3 = Size class; 4 = Diameter of mandibular exopod (d1); 5 = Diameter of antennal exopod (d2); 6 = Diameter of exopod with unclear affinities; $7=$ Diameter of antennal endopod (d3); 8 = Diameter of mandibular endopod; $9=$ Height of antennal coxa in proximal-distal axis (h); $10=$ Length of antennal coxa in median-lateral axis (I).

\begin{tabular}{|c|c|c|c|c|c|c|c|c|c|}
\hline 1 & 2 & 3 & 4 & 5 & 6 & 7 & 8 & 9 & 10 \\
\hline 5.1 & 12449B & III & 61 & 61 & - & 44 & 18 & 71 & 139 \\
\hline 5.2 & $12448 \mathrm{~A}$ & II & 50 & 46 & - & 27 & - & 61 & 96 \\
\hline $5.3-5$ & $12449 \mathrm{~A} 01$ & (II) & 44 & - & - & - & 17 & - & - \\
\hline 6.1 & $12448 B$ & ॥ & 37 & 41 & - & 27 & 16 & - & - \\
\hline 6.2 & $12449 C$ & ॥ & 44 & 42 & - & 27 & - & 51 & 94 \\
\hline 6.3 & 12449A25 & I & 35 & 35 & - & 24 & 14 & - & - \\
\hline 6.4 & 12449A02 & III & 61 & 53 & - & 35 & - & 78 & 114 \\
\hline 6.5 (left) & 12449A03a & II & 39 & 45 & - & 28 & 18 & 55 & 84 \\
\hline 6.5 (right) & $12449 \mathrm{~A} 03 \mathrm{~b}$ & II & 43 & 45 & - & 29 & 21 & 58 & 84 \\
\hline 6.6 & $12449 \mathrm{E}$ & I & 31 & 31 & - & 18 & - & 31 & 68 \\
\hline $6.7-8$ & 12449A04 & III & - & 57 & - & 32 & - & 64 & 131 \\
\hline 7.1 & $12445 \mathrm{D}$ & II & 43 & 51 & - & - & 23 & 73 & 106 \\
\hline 7.2 & 12449A20 & ॥ & - & 41 & - & 28 & - & 61 & 94 \\
\hline 7.3 & 12449A18 & 1 & - & 36 & - & 23 & - & 51 & 64 \\
\hline 7.4 & $12451 \mathrm{~F}$ & II & 45 & 45 & - & - & - & 65 & 96 \\
\hline 7.5 & $12447 C$ & 1 & - & 32 & - & 19 & - & 50 & 62 \\
\hline 7.6 & $12447 \mathrm{~A}$ & II & - & 46 & - & 29 & - & 65 & \\
\hline 7.7 & 12449A22 & II & - & 46 & - & 20 & - & - & - \\
\hline 8.1(bottom) & 12449A05a & II & - & 43 & - & 23 & - & - & - \\
\hline 8.1 (top) & $12449 A 05 b$ & II & - & 41 & - & 28 & - & 64 & 110 \\
\hline 8.2 & 12449A06 & (II) & 41 & - & - & - & - & - & - \\
\hline 8.3 & 12449A08 & 1 & - & 36 & - & 15 & - & - & - \\
\hline 8.4 & 12449A16 & 1 & 34 & 34 & - & - & - & 46 & 90 \\
\hline 8.5 & 12449A09 & III & - & 51 & - & 33 & - & - & - \\
\hline 8.6 & 12449A14 & 1 & - & 32 & - & - & - & 43 & 85 \\
\hline 8.7 & 12449A19 & II & 46 & 44 & - & 25 & - & - & 108 \\
\hline 8.8 & 12447B & II & - & 41 & - & 25 & - & 71 & 99 \\
\hline 8.9 & $12454 \mathrm{C}$ & II & - & 45 & - & - & - & 49 & 106 \\
\hline 9.1 & $12452 B$ & (I) & - & 28 & - & - & 18 & - & - \\
\hline 9.2 & 12449A21 & (II) & - & - & 47 & - & - & - & - \\
\hline 9.3 & 12449A10 & (II-III) & - & - & 53 & - & - & - & - \\
\hline 9.4 & 12451B & 1 & - & 28 & - & 15 & - & - & - \\
\hline 9.5 & $12447 \mathrm{~F}$ & $?$ & - & - & 45 & - & - & - & - \\
\hline 9.6 & $12449 \mathrm{G}$ & (II) & - & - & 44 & - & - & - & - \\
\hline 9.7 & $12454 \mathrm{~F}$ & (II-III) & - & - & 52 & - & - & - & - \\
\hline 9.8 & $12442 \mathrm{E}$ & (II) & - & - & 43 & - & - & - & - \\
\hline 9.9 & $12454 \mathrm{D}$ & $?$ & - & - & - & - & - & - & - \\
\hline 9.10 & $12451 \mathrm{C}$ & II & - & - & - & - & - & 59 & 83 \\
\hline 9.11 & 12449A15 & II & - & - & - & - & - & 42 & 106 \\
\hline 10.1 & $12442 B$ & 1 & - & 25 & - & - & - & - & 68 \\
\hline 10.2 & $12445 \mathrm{~A}$ & (II) & - & - & 39 & - & - & - & - \\
\hline 10.3 & $12447 \mathrm{E}$ & $?$ & - & - & - & - & - & - & - \\
\hline 10.4 & 12447D & (III) & - & - & 60 & - & - & - & - \\
\hline
\end{tabular}


TABLE 1 (continued).

\begin{tabular}{|c|c|c|c|c|c|c|c|c|c|}
\hline 1 & 2 & 3 & 4 & 5 & 6 & 7 & 8 & 9 & 10 \\
\hline 10.5 & 12444B & (II) & - & - & 44 & - & - & - & - \\
\hline 10.6 & $12448 \mathrm{E}$ & (II) & - & - & 39 & - & - & - & - \\
\hline 10.7 & $12448 \mathrm{~F}$ & (III) & - & - & 61 & - & - & - & - \\
\hline 10.8 & 12449A23 & (I) & - & - & 25 & - & - & - & - \\
\hline 10.9 & $12454 \mathrm{G}$ & (I) & - & - & (31) & - & - & - & - \\
\hline 10.10 & $12454 I$ & (I) & - & - & - & (16) & - & - & - \\
\hline 10.11 & $12454 B$ & (II) & - & 39 & - & - & - & - & - \\
\hline 10.12 & $12454 \mathrm{H}$ & (III-III) & - & - & 52 & - & - & - & - \\
\hline 10.13 & 12451D & (III) & - & 53 & - & - & - & - & - \\
\hline 11.1 & $12454 \mathrm{E}$ & (I) & - & 25 & - & - & - & - & - \\
\hline 11.2 & $12442 \mathrm{D}$ & (II) & - & - & 41 & - & - & - & - \\
\hline 11.3 & $12448 \mathrm{G}$ & (II) & - & - & 45 & - & - & - & - \\
\hline 11.4 & $12454 \mathrm{~A}$ & III & 55 & 57 & - & - & - & - & - \\
\hline 11.5 & $12451 \mathrm{~A}$ & 1 & 34 & 36 & - & 22 & 13 & 49 & 78 \\
\hline 11.6 & $12445 \mathrm{~F}$ & II & - & 41 & - & 27 & - & 61 & 102 \\
\hline 11.7 & 12449A17 & $\|$ & 44 & 46 & - & 25 & - & - & - \\
\hline 11.8 & 12449A11 & II & - & 43 & - & 20 & - & 61 & 112 \\
\hline 11.9 & 12449A07 & II & 47 & 45 & - & 33 & 14 & - & - \\
\hline 12.1 & $12451 \mathrm{G}$ & $|-| \mid$ & - & 36 & - & - & - & 41 & 92 \\
\hline 12.2 & $12449 D$ & (III-III) & - & 55 & - & - & - & - & - \\
\hline 12.3 & $12449 A 13$ & (II) & - & 39 & - & - & - & - & - \\
\hline 12.4 & $12448 \mathrm{C}$ & (II) & - & 51 & - & - & - & - & - \\
\hline 12.5 & $12449 \mathrm{~F}$ & 1 & 25 & 25 & - & 19 & - & 28 & 55 \\
\hline 12.6 & 12449A12 & (II-III) & - & - & 54 & - & - & - & - \\
\hline 12.7 & $12452 \mathrm{~A}$ & (III) & - & - & 59 & - & - & - & - \\
\hline 12.8 & 12449A24 & I & - & 33 & - & 19 & - & - & 70 \\
\hline 12.9 & $12451 \mathrm{E}$ & (I) & - & - & - & 17 & - & - & - \\
\hline 13.1 & $12442 \mathrm{~A}$ & (II) & - & 49 & - & - & - & - & - \\
\hline 13.2 & $12444 \mathrm{~A}$ & (II) & - & - & - & - & - & 65 & 99 \\
\hline 13.3 & $12442 C$ & $\|$ & 45 & 41 & - & - & - & - & - \\
\hline 13.4 & $12448 \mathrm{D}$ & 1 & - & 32 & - & - & - & 31 & 64 \\
\hline 13.5 & $12445 E$ & (II) & - & - & 41 & - & - & - & - \\
\hline 13.6 & $12448 \mathrm{H}$ & III & - & 63 & - & 33 & - & 80 & 133 \\
\hline 13.7 & $12445 B$ & (II) & - & - & 49 & - & - & - & - \\
\hline 13.8 & $12447 \mathrm{G}$ & III & - & 65 & - & 39 & - & 65 & 139 \\
\hline 13.9 & $12442 \mathrm{~F}$ & 1 & - & 35 & - & 25 & - & 41 & 78 \\
\hline not a crustacean & $12445 \mathrm{C}$ & - & - & - & - & - & - & - & - \\
\hline
\end{tabular}

ing the largest width of about $-/ 30 / 37 ? \mu \mathrm{m}$. Width tapering distally to about $-/ 12 / 20 \mu \mathrm{m}$ in the distal (sixth) element. Length of elements 1 to 3 each about $-/ 10 / 18 ? \mu \mathrm{m}$, fourth element shorter with $-/ 6 /$ $12 \mu \mathrm{m}$, fifth element about $-/ 16 / 29 \mu \mathrm{m}$ and sixth element longest with $-/ 33 / 45 \mu \mathrm{m}$. Three, possibly four terminal setae on sixth element, between -/80/ - and -/130/- $\mu \mathrm{m}$ long; terminal rim of fifth element with two, possibly three setae, at least $-/ 40 /-\mu \mathrm{m}$ long; fourth element with one shorter seta on lat- eral edge, about -/15/- $\mu \mathrm{m}$ long; third and possibly second element each with one seta medially, about -/50/- $\mu \mathrm{m}$ long; first element possibly with one shorter seta of $-/ 20 /-\mu \mathrm{m}$ length, arising laterally (Figure 5.2).

Second pair of appendages (antennae). Antennae biramous. No details of insertion area or angle between body and antennae known. Antennae consisting of coxa, basipod, endopod and exopod 
TABLE 2. Overview of the most important measurement data in $\mu \mathrm{m}$. Lengths of entire appendages or of exopods and endopods always without terminal setae. Question marks indicate uncertainties due to preservational constraints; dashes mark unavailable data.

\begin{tabular}{lccc}
\multicolumn{1}{c}{ Value } & Stage I & Stage II & Stage III \\
\hline total anterior-posterior body length & 150 & 225 & 300 \\
maximum body width (excl. appendages) & 160 & 185 & 270 \\
maximum dorso-ventral body height & 90 & 145 & 205 \\
antennula length & - & 90 & $150 ?$ \\
antenna length & 190 & 270 & 370 \\
antennal coxa, medio-lateral extension & 75 & 105 & 135 \\
antennal coxa, maximum proximo-distal height & 40 & 60 & 75 \\
antennal endopod length & 60 & 80 & 110 \\
antennal exopod length & 160 & 205 & 280 \\
mandible length & $170 ?$ & 220 & 280 \\
mandibular coxa, medio-lateral extension & - & 45 & 53 \\
mandibular coxa, maximum proximo-distal height & - & $60 ?$ & $75 ?$ \\
mandibular endopod length & $14 ?$ & $18 ?$ & $20 ?$ \\
mandibular exopod length & 130 & 165 & 205
\end{tabular}

(Figures 3.1-2, 5.2). Coxa attached to body, its cross section more or less oval, flattened in anteroposterior axis. Two spines arising medially from an enditic protrusion of the coxa; spines slightly bent proximally, about 45/50/55 $\mu \mathrm{m}$ long. Basipod articulating distally to coxa, oval in cross section (Figure 7.3), about 50/80/- $\mu \mathrm{m}$ long medio-laterally, medially $-/ 10 /-\mu \mathrm{m}$ high; laterally the basipod is proximo-distally very short, only about $-/ 4 /-\mu \mathrm{m}$. Medially two slender spines arising from an enditic protrusion of the basipod; spines bent slightly proximally, about $-/ 22 /-\mu \mathrm{m}$ long (Figures $3.1,5.2$ ).

Endopod arising medio-distally on the basipod. Endopod oval in cross section (measurements accordingly not as exact as for the tubular exopod, see below). Endopod comprising probably three elements (Figure 3.1, 3.5); most proximal element about 21/27/38 $\mu \mathrm{m}$ long and about 20/27/ $35 \mu \mathrm{m}$ wide, next element probably about the same length and width, most distal element smaller with about 13/18/23 $\mu \mathrm{m}$ in length and about the same width. Endopod tip with four setae arising along the distal mid-line, maximally $-/ 45 / 75 \mu \mathrm{m}$ long and pointing distally (Figures $3.1,6.1,7.3$ ). No setation on other endopod elements observed with certainty.

Exopod arising latero-distally on the basipod (Figures 3.1-3, 6.2, 6.4, 6.6, 7). Exopod comprising 12 annuli, decreasing towards the tip of the exopod in their proximo-distal extension: proximal annulus measuring about 22/30/40 $\mu \mathrm{m}$, penultimate annulus $8 / 11 / 14 \mu \mathrm{m}$. Exopod annuli of almost tubular shape, exopod tapering distally: diameter closest to the basipod 30/45/55 $\mu \mathrm{m}$, diameter of the distal edge of the eleventh annulus $16 / 22 / 27 \mu \mathrm{m}$. Special armature on distal rim of exopod annuli 1-11 (especially Figures $3.4,7.7,9.3$ ): One long seta medio-distally of at least 110/230/250 $\mu \mathrm{m}$ length, but probably longer, and a fringe of medium and small setae fully surrounding each of these exopod annuli distally. Medium setae about 11/15/18 $\mu \mathrm{m}$ long, small setae with a length of 5/6/8 $\mu \mathrm{m}$. Diameter of these setae difficult to measure, but apparently up to $3 \mu \mathrm{m}$. Each of the long medio-distal setae flanked by two medium setae. One medium and at least one (proximal annuli) or two (distal annuli) small setae alternating, with about nine to ten medium setae on the proximal annuli and about seven medium setae on the distal annuli (number of setae obviously depending on annulus circumference). The long seta arises from a socket, with about eight spines arising distally from it (Figures $3.4,9.3)$. Long setae subdivided into about six units. The proximal three units each comprising about one quarter of the whole length of the long seta; the three distal units share the distal quarter of the long seta equally (Figure 5.4). Long setae carrying setules, observable in some, but probably present on all long setae (Figures 3.5, 5.4, 6.7, 6.8). Twelfth exopod annulus (distal one) with four long setae of the same style as the long setae of the other annuli, arising and pointing distally in line with the other long setae. 
Third pair of appendages (mandibles). Mandibles resembling the antennae in gross morphology, i.e., being biramous and consisting of coxa, basipod, endopod and exopod (Figures 3.1-3, 6.2, 6.56 ). Also here, no details of insertion area or angle known. Coxa connected to the body, elongate oval in cross section, flattened in antero-posterior axis. Proximally on a median enditic protrusion of the coxa three big spines arise, ca. $-/ 30 /-\mu \mathrm{m}$ long, each carrying probably three spinules proximally; two of the big spines arranged in antero-posterior line, and the third one further antero-distally. One smaller spine arising medio-distally from coxa, ca. $-/ 20 /-\mu \mathrm{m}$ long, slightly bent proximally (Figure 5.3 , 5.5). Basipod arises from coxa distally, probably oval in cross section, i.e., slightly less wide in antero-posterior axis, but exact measurements not possible. Four spines appear to arise medially from the basipod, being slightly curved and pointing medio-proximally (Figure 5.3, 5.5). Spines thinner than the coxal spines, about $-/ 25$ ?/- $\mu \mathrm{m}$ long.

Endopod arising medio-distally from the basipod, comprising only one element of oval outline (Figure 7.3). Approximately as long in proximal-distal axis as in median-lateral axis, with probably five terminal setae along medio-lateral line.

Exopod articulates latero-distally on the basipod. Very similar to antennal exopod, but consisting of only seven annuli (Figures 3.1-3, 6.2, 6.5-6). Exopod $35 / 45 / 60 \mu \mathrm{m}$ in diameter most proximally, distal edge of sixth element about 20/30/45 $\mu \mathrm{m}$ in diameter. Proximo-distal length of annuli declining in distal direction. Setation pattern almost like that on the antennae, but seemingly two long and two short terminal setae on tip.

\section{DISCUSSION}

\section{A eucrustacean nauplius larva}

The term nauplius has often been rather loosely applied to the various larval and immature stages of crustaceans (cf. criticism by Walossek, 1993, 1999; Waloszek, 2003; Haug J.T. et al., 2011). Therefore, we use the term exclusively for the hatching larva with three functional pairs of appendages, as autapomorphically developed in the ground pattern of Eucrustacea, also named orthonauplius (Walossek, 1993; Maas et al., 2003; Waloszek, 2003). Later larvae are termed metanauplii, and depending on the specific eucrustacean in-group there may be several of them. Usually, these can be identified by having more appendages, but the fourth appendage (maxillula) starts out as a small, little-developed bud or even only as a congregation of setae. Hatching as an orthonauplius plus the specific pattern of the subsequent metanaupliar development is understood as constituting a complex autapomorphy of Eucrustacea.

The plesiomorphic state of an ontogeny starting with a hatching stage as a head larva (with four functional limb pairs present), as present in the ground pattern of Euarthropoda (Walossek, 1999), is retained in several early representatives of Crustacea sensu lato known from the 'Orsten' (e.g., Walossek and Müller, 1990; Haug J.T. et al., 2009a, 2010a, b; Haug C. et al., accepted). Such a head larva is also present in the ontogeny of Phosphatocopina, the sister group to Eucrustacea (together constituting Labrophora; Maas et al., 2003; Siveter et al., 2003; Waloszek, 2003). The nauplius retains, in many ways, details of the morphology of the labrophoran head larva, especially in its locomotory and feeding apparatus, which evolved autapomorphically in the ground pattern of Labrophora (Maas et al., 2003; Waloszek, 2003). Accordingly these evolutionary morphological changes have preceded the evolutionary development of the nauplius with its smaller number of functional appendages. In consequence, the nauplius is not a phylogenetically "old" larval type, but represents a new type that first occurred in the stem-species of Eucrustacea.

Using this information, the present material with its specific morphological features can be interpreted as comprising eucrustacean nauplius larvae (Figure 14). The discovery of true nauplii is of significance, as the fossil record of confidently identified nauplii is very scarce and, besides the presented specimens, confined to fossils in 'Orsten'-type preservation (Haug C. et al., accepted). Thus, the presented material enlarges our knowledge about early larvae of fossil eucrustaceans. This is especially important in the light of the different misinterpreted fossils that were originally reconstructed as nauplius larvae (see following section).

\section{Examples of mistakenly interpreted "nauplii"}

There are a number of reports of fossil nauplius larvae in the literature, which must be regarded as misinterpretations. Examples are specimens of Marria walcotti Ruedemann, 1931 (Figure 15.1) and, coupled to it, material assigned to Paramarria Wells, 1944. The material was originally interpreted as nauplii, but has subsequently been recognized as graptolite colonies (Simonetta, 1962). Another fossil species often cited together with Marria and 
Paramarria is Bostrichopus antiquus Goldfuß, 1838. This species is based on a single specimen that has been interpreted as a meta-nauplius of an unknown adult (Hahn, 1967), but the body size of several centimetres is not compatible with a metanauplius. Unfortunately, the specimen could not be found for a re-study.

Material of an arthropod from the Devonian Hunsrück Slate, the marrellomorph Mimetaster hexagonalis Gürich, 1931, has been proposed to represent (meta-)nauplii (Rolfe, 1969). Specimens of the co-occurring marrellomorph Vachonisia rogeri (Lehmann, 1955) have once been interpreted as notostracan branchiopods (Lehmann, 1955), the specimens of $M$. hexagonalis were thought to represent an earlier developmental stage of $V$. rogeri. Today both species are well accepted as separate species, both being representatives of Marrellomorpha (an in-group of Arthropoda sensu stricto having branched off before the euarthropod level) and clearly not crustaceans. Moreover, $V$. rogeri and $M$. hexagonalis are now known from fossils of earlier developmental stages (Kühl et al., 2008; Kühl and Rust, 2010).

\section{Systematic considerations: nauplii of a eubranchiopod species?}

The first attempt to describe the nauplius larvae presented here had been undertaken in the unpublished $\mathrm{PhD}$ thesis of one of the authors (Fayers, 2003). There and in a later publication only briefly mentioning these larvae, the nauplii were addressed as "branchiopod nauplii [...] almost certainly belonging to the anostracan lineage" (Fayers and Trewin, 2004). This estimation was partly influenced by the fact, that all crustaceans found in the Rhynie and Windyfield cherts to that date were ascribed to branchiopods; one species, the extremely abundant Lepidocaris rhyniensis Scourfield, 1926, might be the sister group to Anostraca (Scourfield, 1926, 1940; Walossek, 1993; Olesen, 2004, 2007) or to Eubranchiopoda (Schram and Koenemann, 2001; Olesen, 2004; see Olesen, 2007 for a recent review of the fossil record and interpretations for relationships within Branchiopoda).

Moreover, a misunderstanding of the appendage morphology of the material described herein led to the interpretation of the here presented larvae as anostracan nauplii. This interpretation was based on the identification key for nauplii by Williamson (1982). This key correctly states that for extant branchiopod nauplii the mandible is uniramous. Due to the inconspicuous endopod of the mandible in the Windyfield nauplii, which has not been detected before, the mandible was originally interpreted as uniramous and identified accordingly (Fayers, 2003). Unfortunately, Williamson (1982) did not state that the uniramous state of the mandible in extant branchiopod nauplii is due to the missing exopod, and that the mandibular palp comprises the basipod proximally and the endopod distally. Fayers (2003) already recognised that the mandibular "palp" (his presumed single ramus) is extremely similar to the exopod of the antenna. Our investigation demonstrated that this similarity is due to the fact that the presumed single mandibular ramus indeed represents the exopod, and the endopod is present as well. Consequently, the presence of the exopod on the (in fact biramous) mandible contradicts an in-group position of these larvae within Eubranchiopoda.

\section{Possible relatives in non-marine environments and their abundance in the fossil record}

Branchiopoda. As pointed out above, a eubranchiopod in-group position of the fossils described in this paper is contradicted by our new findings. It is likewise highly unlikely that these nauplii are conspecific with any of the co-occurring crustaceans in the Windyfield/Rhynie chert, which will be explained in the following.

Castracollis wilsonae Fayers and Trewin, 2003 is a eubranchiopod in-group species, probably best interpreted as the sister species to Notostraca or Calmanostraca (cf. Olesen, 2007). No larvae of this species have been described yet, but the original description contains some hints on juveniles within the material (Fayers and Trewin, 2003). Therefore, it is seen as likely that at a certain point larvae of $C$. wilsonae might be found. In any way, based on the phylogenetic position of this species, its larvae should clearly possess eubranchiopod morphology.

Another putative in-group eubranchiopod is Lepidocaris rhyniensis (see Walossek, 1993; Olesen, 2007; but see Schram and Koenemann, 2001 for an opposing view). Of this eucrustacean, described in some detail by Scourfield in 1926, larval stages have become known, though no nauplii, but only later stages with a number of trunk segments (Scourfield, 1940). These larvae have a characteristic eubranchiopod mandible lacking an exopod (Scourfield, 1926, 1940). It is, therefore, proposed that also earlier larvae of $L$. rhyniensis possessed the characteristic eubranchiopod morphology of the mandible, and not the mandibular morphology present in the larvae described here. 
This is supported by the fact that the three successive growth stages present in the material do not reveal any degradation of the exopod of the mandible, which might lead to the assumption of a stepwise reduction during development. Moreover, no details of the larvae described by Scourfield hint to an earlier presence of an exopod in L. rhyniensis.

The third crustacean species from the Windyfield/Rhynie chert is Ebullitiocaris oviformis Anderson, Crighton and Hass, 2004. It was identified as a diplostracan, so again as a eubranchiopod, with supposed close affinities to Cladocera, although the authors were aware of the lack of diagnostic details (Anderson et al., 2004). Cladocerans, however, do not have nauplius larvae besides one exception, the raptorial water flea Leptodora kindtii (Focke, 1844) (see, e.g., Olesen, 1998). All other cladoceran species have an extended embryonic phase and hatch at a far advanced stage.

In the single known Cambrian branchiopod species, the marine Rehbachiella kinnekullensis, putative sister species to Eubranchiopoda (Walossek, 1993), the first stage has about the same size as the nauplii presented here (Table 3, I and II). However, the limbs of $R$. kinnekullensis are shorter and comprise less elements (Table 3, I and II) except for the endopods of both antenna and mandible, which have the highest number of elements compared to any other eucrustacean nauplius (Table 3). The nauplius and successive stages of $R$. kinnekullensis (so being directly comparable to the here described material) have a mandible with well-developed endopod and exopod. In further development the distal basipod and rami become progressively smaller, which can at last be followed up by the reduction in size of the insertion area of the "palp" and, likewise, the development of the coxal body into a large blade-like gnathobase (see Walossek, 1993 for details). Even material assigned to the latest stage known exhibits the compared to earlier stages strongly size-reduced scar of the insertion of the mandibular palp. However, the stepwise-reduction of the palp implies that the adult mandible eventually consists of only the coxal body, which also holds for extant adult branchiopods.

Coincidences between the Windyfield nauplii and those of the best-studied anostracan species, those of the taxon Artemia Leach, 1819, are mainly restricted to the comparatively short endopod of the mandible (Table 3, I and III). The nauplii of species of Artemia are more than twice as long as those presented here but have distinctly different limb details, e.g., a significantly small mandible and an extremely short and undivided mandibular exopod (Table 3, III).

Based on these comparisons, it is possible that the nauplii presented in this paper are the larvae of a species, which branched off from the stem-lineage of Eubranchiopoda or even Branchiopoda, where a larval biramous mandible was present in contrast to the condition in Eubranchiopoda. However, since the biramity of the larval mandible is simply a plesiomorphic condition, its presence is not a positive signal. Hence, there are no positive morphological characters pointing to the assignment of the larvae described herein as representatives of Branchiopoda.

Copepoda. Other entomostracan eucrustaceans with naupliar development are representatives of Maxillopoda. One group also occurring in freshwater today is Copepoda. Astonishingly, the fossil record of Copepoda is even scarcer than that of nauplius larvae. The oldest fossil record of the monophylum including Copepoda (and Mystacocarida; referred to as the 'copepodan line' by Walossek and Müller [1998] and recently termed Copepodoida by Haug J.T. et al., 2011) dates back to the Cambrian. Copepodoida are represented in the Cambrian by three species of the taxon Skara Müller, 1983. Two come from the 'Orsten' of Sweden (Skara anulata Müller, 1983 and S. minuta Müller and Walossek, 1985) and one from China (S. hunanensis Dong in Liu and Dong, 2007). Selden et al. (2010) extended the Copepoda fossil record back into the late Carboniferous in describing crustacean fragments from Oman with supposed copepod affinities. The oldest complete and unequivocal fossil copepod specimen is from the Cretaceous. It was the basis for the description of the apparently parasitic Kabatarina pattersoni Cressey and Boxshall, 1989 and was found on fossil fish material from the Santana formation of Brazil (Cressey and Patterson, 1973; Cressey and Boxshall, 1989). Remarkably, the animal is preserved in an 'Orsten'-like phosphatic 3D preservation exhibiting many delicate details.

Other copepod body fossils of excellent preservation are younger than the Cretaceous, namely from the Miocene and Holocene (Harding, 1956; Palmer, 1960). Miocene finds from the Mojave desert comprise several specimens assigned to the extant harpacticoid taxon Cletocampus (Cletodidae), one of it being an egg-bearing female, and a single specimen of an undetermined cyclopoid (Palmer, 1960). Unfortunately, we could not find the specimens. The single specimen from the Holocene described by Harding (1956) exhibits tre- 
TABLE 3. Comparative data from the first larval stage (nauplius) of selected eucrustacean species; data source given in brackets for each species separately. I. Data of the nauplius described herein. II. Rehbachiella kinnekullensis Müller, 1983 (Branchiopoda) from the Cambrian 'Orsten' of Sweden (Walossek, 1993). III. Artemia sp. from Macau strain, north-eastern Brazil (Schrehardt, 1987). IV. Bryocamptus pygmaeus (Sars, 1862) (Copepoda, Harpacticoida) from fresh water of NW Germany (Dahms, 1987). V. Pseudotachidius sp. (Copepoda, Harpacticoida) from Weddell Sea (Dahms, 1989). VI. Eudiaptomus gracilis (Sars, 1863) (Copepoda, Calanoida) from fresh water of Bavaria, Germany (unpublished data of M. Mayer in the workgroup of D. Waloszek). VII. Monstrilla hamatapex Grygier and Ohtsuka, 1995 (Copepoda, Monstrilloida) from adjacent to Tanabe Bay, Japan (Grygier and Ohtsuka, 1995). VIII. Laura bicornuta Grygier, 1985 (Ascothoracida) from Hawaii (Grygier, 1985). IX. Hansenocaris furcifera Itô, 1989 (Facetotecta) from Tanabe Bay, Japan (Itô, 1990). X. Briarosaccus tenellus Boschma, 1970 (Cirripedia, Rhizocephala) (Walossek et al., 1996). XI. Euphausia superba (Dana, 1852) (Euphausiacea) from Antarctic waters (Fraser, 1936). XII. Macropetasma africanum (Balss, 1913) (Decapoda, Penaeoidea) from off the coast along southern Africa (Cockcroft, 1985). ?= data uncertain or unknown. 0

\begin{tabular}{|c|c|c|c|c|c|c|c|c|c|c|c|c|}
\hline Value & $\mathbf{I}$ & II & III & IV & $\mathbf{v}$ & VI & VII & VIII & IX & $\mathbf{x}$ & $\mathbf{X I}$ & XII \\
\hline total length & 150 & 160 & 350 & 80 & 235 & 135 & 50 & 440 & 280 & 320 & 650 & 250 \\
\hline total width & 160 & $?$ & 120 & 65 & 200 & 75 & 32 & 280 & 170 & 200 & 480 & 130 \\
\hline antennula number of elements & 6 & $?$ & 1 & 3 & 3 & 2 & 3 & 5 & 2 & 3 & 1 & 1 \\
\hline antennula length & $?$ & $?$ & 50 & 25 & 50 & 80 & 12 & 180 & 40 & 130 & 300 & 200 \\
\hline antenna length & 190 & 100 & 200 & 60 & 100 & 100 & 15 & 200 & 80 & 155 & 320 & 200 \\
\hline antennal endopod number of elements & 3 & 4 & 1 & 1 & 1 & 1 & 2 & 3 & 2 & 1 & 1 & 1 \\
\hline antennal endopod length & 60 & 60 & 60 & 40 & 30 & 23 & 10 & 100 & 25 & 75 & 60 & 150 \\
\hline antennal exopod number of annuli & 12 & $7-8$ & $6-8$ & 2 & 5 & 7 & 4 & $8-9$ & 6 & 8 & 1 & 1 \\
\hline antennal exopod length & 160 & 70 & 80 & 20 & 50 & 52 & 8 & 130 & 45 & 90 & 60 & 160 \\
\hline mandible length & $170 ?$ & 85 & 60 & 25 & 60 & 50 & 12 & 180 & 80 & 100 & 300 & 100 \\
\hline mandibular endopod number of elements & 1 & 3 & 1 & 1 & 1 & 1 & $1 ?$ & 3 & 2 & 1 & 1 & 1 \\
\hline mandibular endopod length & $14 ?$ & 45 & 10 & 10 & 10 & 23 & $10 ?$ & 100 & 25 & 30 & 60 & 70 \\
\hline mandibular exopod number of elements & 7 & 7 & 1 & 2 & 2 & 5 & 1 & 7 & 5 & 6 & 1 & 1 \\
\hline mandibular exopod length & 130 & 50 & 10 & 20 & 25 & 24 & 3 & 110 & 40 & 55 & 60 & 70 \\
\hline
\end{tabular}

mendous details including a spermatophore. However, this specimen was partly dissected and only parts of it are still available (Figure 15.2). It was ascribed to the (extant) species Enhydrosoma gariensis Gurney, 1930, and is in fact not really fossil, but best termed subrecent. Downie et al. (1961) discussed the probability of certain microplankton specimens being eggs of copepods. The same idea was proposed for fossil remains from the Holocene by Brenner (2006), who also termed the eggs 'resting stages'. Another indirect fossil record of Copepoda are cysts on Jurassic echinoderms (Radwańska and Radwański, 2005), but which do not provide any morphological details.

Larval development of a variety of species of Copepoda has been well investigated (e.g., Dahms, 1990; Ferrari and Dahms, 2007). Copepoda include species, of which morphological changes including size changes in the early larval phase are, mainly due to lecithotrophy, minor, which is comparable to the condition observed in the larvae described herein. Harpacticoid larvae are usually equipped with appendages with abun- dant setae to be able to feed from the hatching stage (e.g., Paramphiascella fulvofasciata Rosenfield and Coull, 1974; see Dahms, 1990) or at least from the second stage onward (Dahms, 1989). Lecithotrophic larvae usually lack feeding setation completely. Copepod nauplii may have a distinctly different size from the nauplii presented here, but their limb details, i.e., size and number of elements, generally match (Table $3, I V-V I)$, although also significant differences occur (Table 3, VII).

Dahms (2004) reconstructed morphological details of the nauplius in the ground pattern of Copepoda. This includes a tri-partite antennula and an undivided antennal endopod, present at least in the two harpacticoid species considered herein, but partly not in the monstrilloid and the calanoid (Table 3, IV-VII). Unfortunately, Dahms (2004) did not discuss further values that we included (Table 3 ). The mandible may be much smaller than the antenna (Table 3, IV-VI) but not as significantly as in Artemia sp. The two appendages may also be more or less identical in size, element number, and armature (see Nagasawa et al., 1988 for the naup- 
lius of the parasitic copepod Pectenophilus ornatus Nagasawa, Bresciani and Lützen, 1988). The naupliar mandible of Monstrilla hamatapex Grygier and Ohtsuka, 1995 is considerably different from the antenna, since the mandibular endopod seems to be an undivided curved claw flanked by a likewise curved seta (Grygier and Ohtsuka, 1995, figure 4B; see the same authors for a discussion of the endopodal nature). In contrast to Branchiopoda and probably due to heterochronic events in the early evolution of Maxillopoda, the mandible of copepods never loses its palp, i.e., the adults have a mandible comprising coxa, basipod and two rami (Waloszek, 2003).

\section{Possible thecostracan affinities}

A basipod morphology similar to that of the Windyfield nauplii can be found in the other evolutionary lineage of Maxillopoda, the thecostracan lineage. One ingroup with rather strong similarities in naupliar morphology to the Windyfield material is the Ascothoracida (e.g., Grygier, 1985; Table 3, VIII). In this group the antennal endopods consist of three elements and the mandibular exopod of seven elements, both as in the nauplii presented here. Antennae and mandibles in ascothoracid nauplii in general closely resemble each other morphologically (e.g., Boxshall and Böttger-Schnack, 1988), which also holds for cirripede nauplii (see, e.g., Walossek et al., 1996 for the rhizocephalan Briarosaccus tenellus Boschma, 1970). Further similarities between ascothoracid nauplii and those presented here concern the relatively high number of antennular elements, the rather long antennae and mandibles as well as the long antennular and mandibular exopods (the length of an appendage and that of its exopod is, of course, coupled; Table 3 , I and VIII). This accumulation of similar morphological traits, which cannot all be interpreted as plesiomorphies, may point to an affinity of these fossil nauplii with Ascothoracida.

There is no significant morphological coincidence between the nauplii described herein and those of the two other thecostracan groups Facetotecta (Table 3, IX) and Rhizocephala (Table 3, X). Nevertheless, there is an interesting similarity concerning the development of the fossil nauplii and rhizocephalan ones. The larval phase of Rhizocephala, parasitic thecostracans, is characterized by a size stagnation or even decrease from the nauplius towards the last (fourth) metanauplial stage. Even the following cyprid stage is smaller, e.g., in Briarosaccus tenellus Boschma, 1970, than the preceding metanauplial stage, considering the entire body size as well as the sizes of the appendages (Walossek et al., 1996). Rhizocephalan larvae are lecithotrophic, a conclusion drawn by the absence of enditic protrusions on both antenna and mandible and the weak feeding setation on the two limbs (Walossek et al., 1996).

\section{Malacostracan nauplii}

Among Malacostraca, nauplii occur today only in Euphausiacea and Decapoda. These nauplii are lecithotrophic. Their limbs are armed with swimming setation, but they lack feeding setation and, again, the swimming setae lack setulae. A functional feeding setation, e.g., in the penaeid Macropetasma africanum Balss, 1913 does not develop before reaching a stage with 14 trunk segments, i.e., the segmental condition of the adult (cf. Cockcroft, 1985). Comparisons of limb details do not reveal conspicuous morphological conformities between the nauplii described herein (Table $3, \mathrm{I}$ ) and representatives of Malacostraca (Table 3, XI, XII).

\section{Ecological aspects}

While thecostracan affinities of the nauplii presented here may morphologically well be possible, the environmental conditions interpreted from sedimentology, fossils, and palaeogeography for the Rhynie/Windyfield area in the Early Devonian do not argue in favour of this assumption. There is no evidence for any marine influence in the sedimentology or macrobiota, and extensive palynological preparations (Wellman, 2006) are similarly devoid of marine elements. Rhynie was a very long way from marine conditions in the Early Devonian, even to the extent that no fish have been found in the basin that might indicate a distant connection for migration. Freshwater would have flowed in the main river, but some of the small pools in the hotspring area would have had variable chemistry due to eruption of hydrothermal waters responsible for silica deposition, and the origin of the cherts (Trewin et al., 2003). Thus salinity (and pH and temperature) would have varied in the ephemeral hot-spring pools.

On the micro-environmental scale the chert containing the larvae was found in situ in a trench excavation at Windyfield (Trench T3, see Anderson and Trewin, 2003). It comprised a fragmented chert and cherty sandstone bed up to $15 \mathrm{~cm}$ thick extending laterally for about a metre, and enclosed in hydrothermally altered shale. The biota of this chert bed is characterised by a strong terrestrial input with trigonotarbids (Palaeocharinus tubercu- 
latus Fayers, Dunlop and Trewin, 2005), centipedes, eoarthropleurids, and degraded Rhynia gwynne-vaughanii Kidston and Lang, 1917, which was growing at the site (see Appendix 9). This terrestrial community was flooded, and a freshwater biota appeared with charophyte algae, microbial mats and the crustacean larvae. The chert shows the textures typical of freshwater pools as described by Trewin et al. (2003). Hot-spring activity flooded the pool with silica-rich waters, preserving the biota. The larvae described here had probably hatched from eggs when the freshwater pool was formed, and their lives were cut short when hot-spring waters invaded the pool. Thus, these aquatic crustaceans were unable to complete their life cycle, and no conspecific aquatic adult has as yet been found in this bed.

The dispersal of aquatic arthropods in nonmarine environments, particularly where small ephemeral pools are involved poses problems. Branchiopoda overcame this problem with eggs that withstand desiccation, and can be wind-transported, combined with a rapid development to maturity. It seems impossible at present to explain how any arthropod from a marine environment could have colonised the Rhynie area in the Early Devonian. Branchiopoda and Copepoda are among the few crustacean ingroups today that include fresh-water species with a naupliar stage. Accordingly, from an ecological-phylogenetic point of view, these two groups would be the best candidates for the assignment of the larvae described herein. Possibly the nauplii presented in this paper are the larvae of a species which branched off from the stem-lineage of Eubranchiopoda or even Branchiopoda, where a larval biramous mandible was present in contrast to the condition in Eubranchiopoda.

Although the morphological similarities of the material presented here to thecostracan nauplii are very high, the occurrence of thecostracans in the Windyfield chert would be exceptional, because extant thecostracans are exclusively marine, and they have no non-marine fossil record. Yet, it cannot be excluded that an unusual representative of Thecostraca found its way into a non-marine environment in convergence to many other crustacean lineages. Concerning Malacostraca, all species living today that retained a nauplius in their larval phase, i.e., Dendrobranchiata among Decapoda and Euphausiacea, are marine as well, and there are no morphological traits hinting to malcostracan affinities of the fossil nauplii (see above).

\section{CONCLUSION}

Currently it remains impossible to assign the nauplii described here to a certain species or to reliably determine their exact phylogenetic placement. Their morphology contradicts earlier assumed eubranchiopod affinities, but it cannot be excluded that they are representatives of a species, which derived from the early branchiopod lineage below the evolutionary level of Eubranchiopoda. Alternatively, these larvae could also be representatives of Maxillopoda. For a final determination of the phylogenetic position of the species represented by these fossil larvae information of later ontogenetic stages is necessary. Details on the ontogeny of a variety of species are necessary for a sound assignment of the nauplii described herein, and future work should include investigations on the accumulation of such data.

\section{ACKNOWLEDGMENTS}

Thanks are due to S. Liebau, University of UIm, for providing access to the Zeiss Axioskop 2 and for his long-lasting support. We are also grateful to D. Erwin, J. Thompson, and M. Florence from the National Museum of Natural History of the Smithsonian Institution, Washington, D.C. (USNM) and to C. Mellish, A. Glover, and M. Packer from the Natural History Museum, London (NHM) for providing access to the collections and microscopes. Further thanks go to J. Rust, T. Wappler and other colleagues from the Steinmann Institute of the University of Bonn for their attempt to locate the single specimen of Bostrichopus antiquus. A. Channing, Cardiff University, is thanked for stimulating discussions. M. Mayer, Wilhelmshaven, provided the data on Eudiaptomus gracilis used in Table 3. We also like to thank all people involved in the programming of free software, which was used in the course of this study, i.e., Blender, CombineZM, Gimp, ImageJ, OpenOffice, and OsiriX. H. Kerp, Münster, and an anonymous reviewer gave helpful comments on the manuscript. The research trip of J.T. Haug to London was funded by a grant from the European Commission's (FP 6) Integrated Infrastructure Initiative programme SYNTHESYS (GB-TAF-4733). J.T. Haug was kindly funded by the German Research Foundation (DFG) under Wa 754/15-1 and is currently funded by the Alexander von Humboldt-Foundation with a Feodor Lynen Fellowship for postdoctoral researchers. C. Castellani was kindly funded by the DFG under Wa 754/18-1. Finally, C. Haug and J.T. Haug would like to thank their host D.E.G. Briggs, Yale University 
and Yale Peabody Museum, New Haven, for his support.

\section{REFERENCES}

Adamczak, F. 1958. The ontogeny and evolution of Kozlowskiella (Přibyl) (Ostracoda). Acta Palaeontologica Polonica, 3:75-116.

Anderson, L.I. and Trewin, N.H. 2003. An Early Devonian arthropod fauna from the Windyfield cherts, Aberdeenshire, Scotland. Palaeontology, 46:467509.

Anderson, L.I., Crighton, W.R.B., and Hass, H. 2004. A new univalve crustacean from the Early Devonian Rhynie chert hot-spring complex. Transactions of the Royal Society of Edinburgh: Earth Sciences, 94:355369.

Balss, H., 1913. Decapode Crustaceen. In Schultze, L. (ed.) Zoologische und Anthropologische Ergebnisse einer Forschungsreise in Südafrika, vol. 5 pt. 2. Denkschriften der medizinisch-naturwissenschaftichen Gesellschaft zu Jena, 17:103-110.

Becker, G. 2005. Functional morphology of Palaeozoic ostracods: phylogenetic implications. Hydrobiologia, 538:23-53.

Boll, E. 1856. Herr Boll an Herrn Beyrich. Zeitschrift der Deutschen Geologischen Gesellschaft, 8: 321-324.

Boschma, H. 1970. Notes of Rhizocephala of the genus Briarosaccus, with description of a new species. Proceedings of the koninklijke nederlandse Akademie van Wetenschappen, series C, Biological and Medical Sciences, 73:233-242.

Boxshall, G.A. and Böttger-Schnack, R. 1988. Unusual ascothoracid nauplii from the Red Sea. Bulletin of the British Museum (Natural History), Zoology series, 54:275-283.

Braun, A. 1997. Vorkommen, Untersuchungsmethoden und Bedeutung tierischer Cuticulae in kohligen Sedimentgesteinen des Devons und Karbons. Palaeontographica B, 245:83-156.

Brenner, W.W. 2006. Organische Mikrofossilien der holozänen Ostsee. Meyniana, 58:33-55.

Cockcroft, A.C. 1985. The larval development of Macropetasma africanum (Balss, 1913) Decapoda, Penaeoidea) reared in the laboratory. Crustaceana, 49:5274.

Cooper, C.L. 1945. Moult stages of the Pennsylvanian ostracode Ectodemites plummeri. Journal of Palaeontology, 19:368-375.

Cressey, R. and Boxshall, G. 1989. Kabatarina pattersoni, a fossil parasitic copepod (Dichelesthiidae) from a Lower Cretaceous fish. Micropaleontology, 35:150-167.

Cressey, R. and Patterson, C. 1973. Fossil parasitic copepods from a Lower Cretaceous fish. Science, 180:1283-1285.

Dahms, H.-U. 1987. Die Nauplius-Stadien von Bryocamptus pygmaeus (Sars, 1862) (Copepoda, Harpacticoida, Canthocamptidae). Drosera, 1:47-58.
Dahms, H.-U. 1989. First record of a lecithotrophic nauplius in Harpacticoida (Crustacea, Copepopda) collected from the Weddell Sea (Antarctica). Polar Biology, 10:221-224.

Dahms, H.-U. 1990. Naupliar development of Harpacticoida (Crustacea, Copepoda) and its significance for phylogenetic systematics. Microfauna Marina, 6:169272.

Dahms, H.-U. 2004. Postembryonic apomorphies proving the monophyletic status of the Copepoda. Zoological Studies, 43:446-453.

Dana, J.D. 1852. Crustacea. Part II. United States Exploring Expedition during the years 1838, 1839, 1840, 1841, 1842 under the command of Charles Wilkes, U.S.N. 13: 689-1618.

Downie, C., Williams, G.L. and Sarjeant, W.A.S. 1961. Classification of fossil microplancton. Nature, 4801:471.

Fayers, S.R. 2003. The biota and palaeoenvironments of the Windyfield chert, Early Devonian, Rhynie, Scotland. Unpublished $\mathrm{PhD}$ thesis, University of Aberdeen, Aberdeen, UK.

Fayers, S.R. and Trewin, N.H. 2003. A new crustacean from the Early Devonian Rhynie chert, Aberdeenshire, Scotland. Transactions of the Royal Society of Edinburgh: Earth Sciences, 93:355-382.

Fayers, S.R. and Trewin, N.H. 2004. A review of the palaeoenvironments and biota of the Windyfield chert. Transactions of the Royal Society of Edinburgh: Earth Sciences, 94:325-339.

Fayers, S.R., Dunlop, J.A., and Trewin, N.H. 2005. A new early Devonian trigonotarbid arachnid from the Windyfield chert, Rhynie, Scotland. Journal of Systematic Palaeontology, 2:269-284.

Ferrari F.D. and Dahms H.-U. 2007. Post-embryonic development of the Copepoda. Crustaceana Monographs, 8:1-229.

Focke, G.W. 1844. Polyphemus kindtii. Amtlicher Bericht über die 22. Versammlung deutscher Naturforscher und Ärzte in Bremen. Weser-Zeitung Sonntagsblatt, $32: 6-7+1 \mathrm{pl}$

Fraser, F.C. 1936. On the development and distribution of the young stages of krill (Euphausia superba). Discovery Reports, 14:1-192.

Goldfuß, G.A. 1838. Beiträge zur Petrefaktenkunde. B. Beiträge zur Familie der fossilen Crustaceen. 1. Bostrichopus antiquus. Nova Acta Academiae Caesareae Leopoldino Carolinae Naturae Curiosorum, 19:27-29.

Gramann, F. 1962. Extremitätenfunde an liassischen Bairdien. Paläontologische Zeitschrift, 36:28-32.

Grygier, M.J. 1985. Lauridae: taxonomy and morphology of the ascothoracid crustacean parasites of zooanthids. Bulletin of Marine Science, 36:278-303.

Grygier, M.J. and Ohtsuka, S. 1995. SEM observation of the nauplius of Monstrilla hamatapex, new species, from Japan and an example of upgraded descriptive standards for monstrilloid copepods. Journal of Crustacean Biology, 15:703-719. 
Gürich, G. 1931. Mimetaster hexagonalis, ein neuer Kruster aus dem unterdevonischen Bundenbacher Dachschiefer. Paläontologische Zeitschrift, 12:204238.

Gurney, R. 1930. Two new species of estuarine Copepoda. Zoologischer Anzeiger, 87:321-326.

Hahn, G. 1967. Zur Stellung von Bostrichopus. Neues Jahrbuch für Geologie und Paläontologie, Abhandlungen, 127:264-287.

Harding, J.P. 1956. A rare estuarine copepod crustacean, Enhydrosoma garienis, found in the Holocene of Kent. Nature, 178:1127-1128.

Hartmann, G. 1967. Ostracoda, p.1-786. In Bronn, H.G. (ed.), Klassen und Ordnungen des Tierreichs, Bd. 5: Arthropoda, Abt. 1: Crustacea, 2. Buch, 4. Teil, 1-4. Lieferung. Akademische Verlagsgesellschaft Geest and Portig K.-G., Leipzig.

Haug, C., Haug, J.T., Maas, A., and Waloszek, D. accepted. Fossil larvae in 'Orsten' preservation. In Martin, J.W., Olesen, J. and Høeg, J.T. (eds.), Atlas of Crustacean Larvae.

Haug, J.T., Maas, A., and Waloszek, D. 2009a. Ontogeny of two Cambrian stem crustaceans, †Goticaris longispinosa and †Cambropachycope clarksoni. Palaeontographica A, 289:1-43.

Haug, J.T., Maas, A., and Waloszek, D. 2010a. †Henningsmoenicaris scutula, †Sandtorpia vestrogothiensis gen. et sp. nov. and heterochronic events in early crustacean evolution. Earth and Environmental Science Transactions of the Royal Society of Edinburgh, 100:311-350.

Haug, J.T., Olesen, J., Maas, A., and Waloszek, D. 2011. External morphology and post-embryonic development of Derocheilocaris remanei (Mystacocarida) revisited, with a comparison to the Cambrian taxon Skara. Journal of Crustacean Biology, 31:668-692.

Haug, J.T., Waloszek, D., Haug, C., and Maas, A. 2010b. High-level phylogenetic analysis using developmental sequences: The Cambrian †Martinssonia elongata, †Musacaris gerdgeyeri gen. et sp. nov. and their position in early crustacean evolution. Arthropod Structure and Development, 39:154-173.

Haug, J.T., Haug, C., Maas, A., Fayers, S.R., Trewin, N.H., and Waloszek, D. 2009b. Simple 3D images from fossil and Recent micromaterial using light microscopy. Journal of Microscopy, 233:93-101.

Itô, T. 1989. A new species of Hansenocaris (Crustacea: Facetotecta) from Tanabe Bay, Japan. Publications of the Seto Marine Biological Laboratory, 34:55-72.

Itô, T. 1990. Naupliar development of Hansenocaris furcifera Itô (Crustacea: Maxillopoda: Facetotecta) from Tanabe Bay, Japan. Publications of the Seto Marine Biological Laboratory, 34:201-224.

Kelman, R., Feist, M., Trewin, N.H., and Hass, H. 2004. Charophyte algae from the Rhynie chert. Transactions of the Royal Society of Edinburgh: Earth Sciences, 94:445-455.
Kidston, R. and Lang, W.H. 1917. On Old Red Sandstone plants showing structure, from the Rhynie chert bed, Aberdeenshire. Part I. Rhynia gwynnevaughanii Kidston and Lang. Transactions of the Royal Society of Edinburgh, 51:761-784.

Kidston, R. and Lang, W.H. 1921. On Old Red Sandstone plants showing structure, from the Rhynie Chert bed, Aberdeenshire. Part V. The Thallophyta occurring in the peat-bed; the succession of the plants throughout a vertical section of the bed, and the conditions of accumulation and preservation of the deposit. Transactions of the Royal Society of Edinburgh, 52:855-902.

Kühl, G. and Rust, J. 2010. Re-investigation of Mimetaster hexagonalis: a marrellomorph arthropod from the Lower Devonian Hunsrück Slate (Germany). Paläontologische Zeitschrift, 84:397-411.

Kühl, G., Bergström, J., and Rust, J. 2008. Morphology, palaeobiology and phylogenetic position of Vachonisia rogeri (Arthropoda) from the Lower Devonian Hunsrück Slate (Germany). Palaeontographica $A$, 286:123-157.

Lehmann, W.M. 1955. Vachonia rogeri n.g.n.sp. ein Branchiopod aus dem unterdevonischen Hunsrückschiefer. Paläontologische Zeitschrift, 29:126130.

Liu, J. and Dong, X. 2007. Skara hunanensis a new species of Skaracarida (Crustacea) from Upper Cambrian (Furongian) of Hunan, south China. Progress in Natural Science, 17:934-942.

Maas, A., Braun, A., Dong X.-p., Donoghue, P.C.J., Müller, K.J., Olempska, E., Repetski, J.E., Siveter, D.J., Stein, M., and Waloszek, D. 2006. The 'Orsten' - more than a Cambrian Konservat-Lagerstatte yielding exceptional preservation. Palaeoworld, 15:266282.

Maas, A., Waloszek, D., and Müller, K.J. 2003. Morphology, ontogeny and phylogeny of the Phosphatocopina (Crustacea) from the Upper Cambrian "Orsten" of Sweden. Fossils and Strata, 49:1-238.

Mark, D.F., Rice, C.M., Fallick, A.E., Trewin, N.H., Lee, M.R., Boyce, A., and Lee, J.K.W. 2011. ${ }^{40} \mathrm{Ar} /{ }^{39} \mathrm{Ar}$ dating of hydrothermal activity, biota and gold mineralisation in the Rhynie hot-spring system, Aberdeenshire, Scotland. Geochimica et Cosmochimica Acta, 75:555-569.

Müller, K.J. 1983. Crustacea with preserved soft parts from the Upper Cambrian of Sweden. Lethaia, 16:93109.

Müller, K.J. and Walossek, D. 1985. Skaracarida, a new order of Crustacea from the Upper Cambrian of Västergötland, Sweden. Fossils and Strata, 17:1-65.

Müller, K.J. and Walossek D. 1986. Arthropod larvae from the Upper Cambrian of Sweden. Transactions of the Royal Society of Edinburgh: Earth Sciences, 77:157-179. 
Müller, K.J. and Walossek, D. 1988. External morphology and larval development of the Upper Cambrian maxillopod Bredocaris admirabilis. Fossils and Strata, 23:1-70.

Nagasawa, K., Bresciani, J., and Lützen, J. 1988. Morphology of Pectenophilus ornatus, new genus, new species, a copepod parasite of the Japanese scallop Patinopecten yessoensis. Journal of Crustacean Biology, 8:31-42.

Olesen, J. 1998. A phylogenetic analysis of the Conchostraca and Cladocera (Crustacea, Branchiopoda, Diplostraca). Zoological Journal of the Linnean Society, 122:491-536.

Olesen, J. 2004. On the ontogeny of the Branchiopoda (Crustacea): contribution of development to phylogeny and classification, p. 217-269. In Scholtz, G. (ed.), Evolutionary Developmental Biology of Crustacea. Crustacean Issues 15. A.A. Balkema Publishers, Lisse, Abingdon, Exton (PA), Tokyo.

Olesen, J. 2007. Monophyly and phylogeny of Branchiopoda, with focus on morphology and homologies of branchiopod phyllopodous limbs. Journal of Crustacean Biology, 27:165-183.

Palmer, A.R. 1960. Miocene copepods from the Mojave desert, California. Journal of Paleontology, 34:447$452+1$ pl.

Parry, S.F., Noble, S.R., Crowley, Q.G., and Wellman, C.H. 2011. A high precision $\mathrm{U} / \mathrm{Pb}$ age constraint on the Rhynie Chert Konservat-Lagerstatte: time scale and other implications. Journal of the Geological Society, 168:863-872.

Radwańska, U. and Radwański, A. 2005. Myzostomid and copepod infestation of Jurassic echinoderms: A general approach, some new occurrences, and/or reinterpretation of previous reports. Acta Geologica Polonica, 55:109-130.

Rice, C.M. and Ashcroft, W.A. 2004. The geology of the northern half of the Rhynie Basin, Aberdeenshire, Scotland. Transactions of the Royal Society of Edinburgh: Earth Sciences, 94:299-308.

Rice, C.M., Trewin, N.H., and Anderson, L.I. 2002. Geological setting of the Early Devonian Rhynie cherts, Aberdeenshire, Scotland: an early terrestrial hot spring system. Journal of the Geological Society London, 159:203-214.

Rolfe, W.D.I. 1969. Arthropoda incertae sedis, p. R620R625. In Moore, R.C. (ed.), Treatise on Invertebrate Paleontology. Part R, Arthropoda 4, vol. 2. The Geological Society of America, Inc., Boulder.

Rosenfield, D.C. and Coull, B.C. 1974. Adult morphology and larval development of Paramphiascella fulvofasciata n.sp. (Copepoda, Harpacticoida) Cahiers de Biologie Marine, 15:295-317.

Roy, K. and Fåhræus, L.E. 1989. Tremadocian (Early Ordovician) nauplius-like larvae from the Middle Arm Point formations, Bay of Islands, western Newfoundland. Canadian Journal of Earth Sciences, 26:18021806.
Ruedemann, R. 1931. Some new Middle Cambrian fossils from British Columbia. Proceedings of the United States National Museum, 78:1-18.

Sars, G.O. 1862. Hr. Studios. medic. G. O. Sars meddeelte en af talrige Atbildninger ledsaget Oversigt af de af ham i Omegnen af Christiania iagttagne Crustacea Cladocera. Forhandlinger $i$ Videnskabs-Selskabet i Christiania, 1861:144-167; 250-302.

Sars, G.O. 1863. Bereting om en I Sommeren 1862 foretagen zoologisk Reise I Christianias og Trondhgems stifter. Nyt Magazin für Naturvidenskaberne, Christiana/Oslo, 12:193-252.

Schram, F.R. and Koenemann, S. 2001. Developmental genetics and arthropod evolution: part I, on legs. Evolution and Development, 3:343-354.

Schrehardt, A. 1987. A scanning electron-microscope study of the post-embryonic development of Artemia, p. 5-32. In Sorgeloos, P., Bengtson, D.A., Decleir, W., and Jaspers, E. (eds.), Artemia Research and its Applications Vol. 1. Morphology, Genetics, Strain chracaterisation, Toxicology. Universa Press, Wetteren, Belgium.

Scourfield, D.J. 1926. On a new type of crustacean from the Old Red Sandstone (Rhynie Chert Bed, Aberdeenshire) - Lepidocaris rhyniensis gen. et sp. nov. Philosophical Transactions of the Royal Society of London, 214:153-187.

Scourfield, D.J. 1940. Two new and nearly complete specimens of young stages of the Devonian fossil crustacean Lepidocaris rhyniensis. Proceedings of the Linnean Society, 152:290-298.

Selden, P.A., Huys, R., Stephenson, M.H., Heward, A.P., and Taylor, P.N. 2010. Crustaceans from bitumen clast in Carboniferous glacial diamictite extend fossil record of copepods. Nature Communications, 1 art. 50, doi:10.1038/ncomms1049

Simonetta, A.M. 1962. Osservazioni su Marria walcotti Ruedemann: un graptolite e non un artropodo. Bolletino di Zoologica, 28:569-572.

Siveter, D.J., Waloszek, D., and Williams, M. 2003. An Early Cambrian phosphatocopid crustacean with three-dimensionally preserved soft parts from Shropshire, England. In Lane, P.D., Siveter, D.J., and Fortey, R.A. (eds.), Trilobites and their Relatives. Special Papers in Palaeontology, 70:9-30.

Smith, R.J. 2000. Morphology and ontogeny of Cretaceous ostracods with preserved appendages from Brazil. Palaeontology, 43:63-98.

Spjeldnæs, N. 1951. Ontogeny of Beyrichia jonesi Boll. Journal of Palaeontology, 25:745-755.

Stein, M., Waloszek, D., Maas, A., Haug, J.T., and Müller, K.J. 2008. The stem crustacean Oelandocaris oelandica re-visited. Acta Palaeontologica Polonica, 53:461-484.

Trewin, N.H. 2004. History of research on the geology and palaeontology of the Rhynie area, Aberdeenshire, Scotland. Transactions of the Royal Society of Edinburgh: Earth Sciences, 94:285-297. 
Trewin, N.H. and Wilson, E. 2004. Correlation of the Early Devonian Rhynie chert beds between three boreholes at Rhynie, Aberdeenshire. Scottish Journal of Geology, 40:73-81.

Trewin, N.H., Fayers, S.R., and Kelman, R. 2003. Subaqueous silicification of the contents of small ponds in an Early Devonian hot-spring complex, Rhynie, Scotland. Canadian Journal of Earth Sciences, 40:1697-1712.

Walossek, D. 1993. The Upper Cambrian Rehbachiella and the phylogeny of Branchiopoda and Crustacea. Fossils and Strata, 32:1-202.

Walossek, D. 1999. On the Cambrian diversity of Crustacea, p. 3-27. In Schram, F.R. and von Vaupel Klein, J.C. (eds.), Crustaceans and the Biodiversity Crisis. Proceedings of the Fourth International Crustacean Congress, Amsterdam, The Netherlands, July 20-24, 1998, vol.I. Brill, Leiden.

Waloszek, D. 2003. Cambrian 'Orsten'-type preserved arthropods and the phylogeny of Crustacea, p. 6987. In Legakis, A., Sfenthourakis, S., Polymeni, R., and Thessalou-Legaki, M. (eds.), The New Panorama of Animal Evolution. Proceedings of the 18th International Congress of Zoology, Pensoft Publishers, Sofia, Moscow.

Walossek, D. and Müller, K.J. 1989. A second type Anauplius from the Upper Cambrian 'Orsten' of Sweden. Lethaia, 22:301-306.

Walossek, D. and Müller, K.J. 1990. Upper Cambrian stem-lineage crustaceans and their bearing upon the monophyletic origin of Crustacea and the position of Agnostus. Lethaia, 23:409-427.

Walossek, D. and Müller, K.J. 1998. Early arthropod phylogeny in light of the Cambrian "Orsten" fossils, $p$. 185-231. In Edgecombe, G.D. (ed.), Arthropod Fossils and Phylogeny. Columbia University Press, New York.
Walossek, D., Høeg, J.T., and Shirley, T.C. 1996. Larval development of the rhizocephalan cirripede Briarosaccus tenellus (Maxillopoda: Thecostraca) reared in the laboratory: a scanning electron microscopy study. Hydrobiologia, 328:9-47.

Walossek, D., Hinz-Schallreuter, I., Shergold, J.H., and Müller, K. J. 1993. Three-dimensional preservation of arthropod integument from the Middle Cambrian of Australia. Lethaia, 26:7-15.

Weitschat, W. 1983. Ostracoden (O. Myodocopida) mit Weichkörper-Erhaltung aus der Unter-Trias von Spitzbergen. Paläontologische Zeitschrift, 57:309323.

Wellman, C. H, 2006. Spore assemblages from the Lower Devonian 'Lower Old Red Sandstone' of the Rhynie outlier, Scotland. Transactions of the Royal Society of Edinburgh: Earth Sciences, 97: 167-211.

Wells, J.W. 1944. Two new planktonic crustaceans from the Maquoketa shale (Ordovician of Illinois). American Journal of Science, 242:436-441.

Williams, M., Siveter, D.J., Ashworth, A.C., Wilby, P.R., Horne, D.J., Lewis, A.R., and Marchant, D.R. 2008. Exceptionally preserved lacustrine ostracods from the Middle Miocene of Antarctica: Implications for high-latitude palaeoenvironment at $77^{\circ}$ south. Proceedings of the Royal Society B: Biological Sciences, 275:2449-2454.

Williamson, D.I. 1982. Larval morphology and diversity, p. 43-110. In Abele, L.G. (ed.), The Biology of Crustacea, Volume 2: Embryology, Morphology and Genetics. Academic Press, New York.

Zhang, X.-g., Maas, A., Haug, J.T., Siveter, D.J., and Waloszek, D. 2010. A eucrustacean metanauplius from the Lower Cambrian. Current Biology, 20:10751079. 


\section{APPENDIX 1.}

Overview of specimens on thin section AUGD 12442.

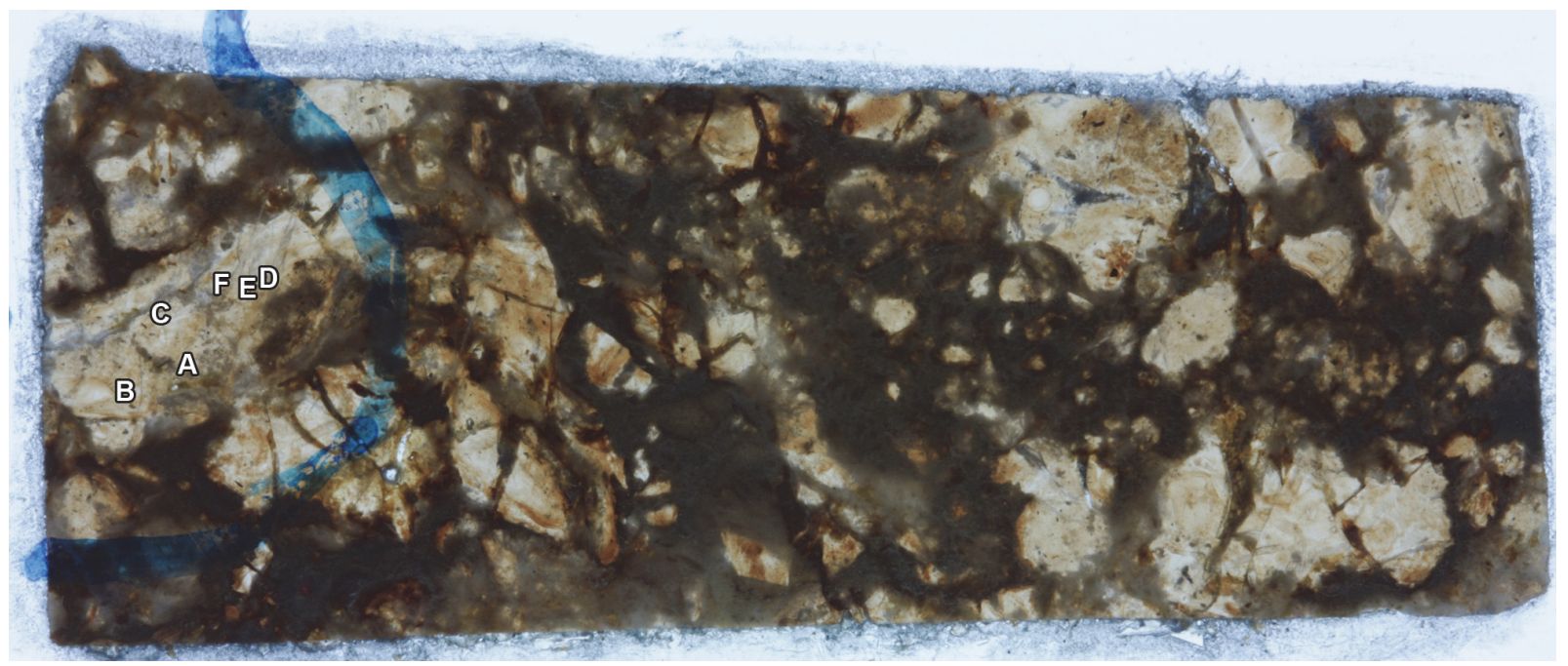




\section{APPENDIX 2.}

Overview of specimens on thin section AUGD 12444.

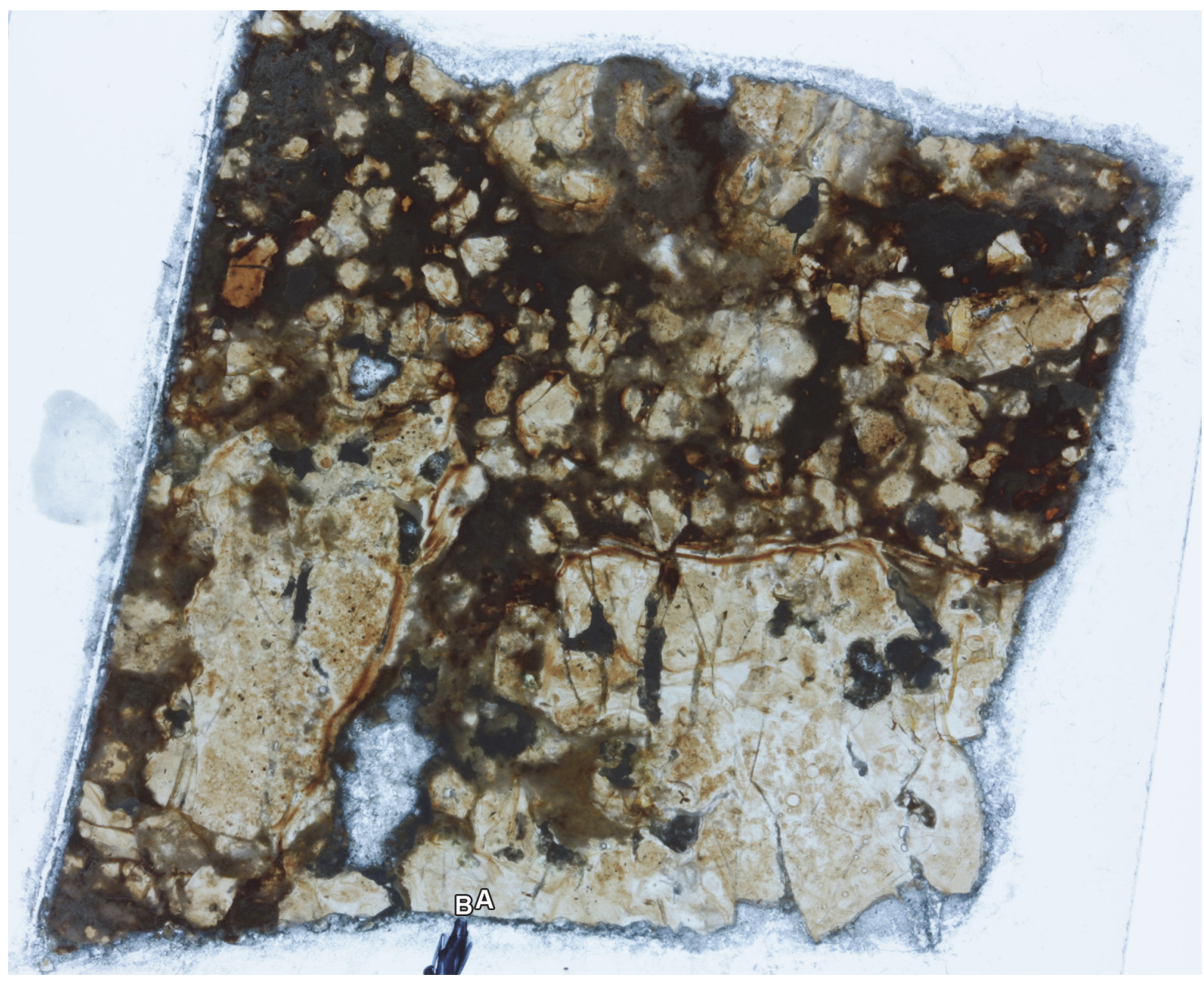




\section{APPENDIX 3.}

Overview of specimens on thin section AUGD 12445.

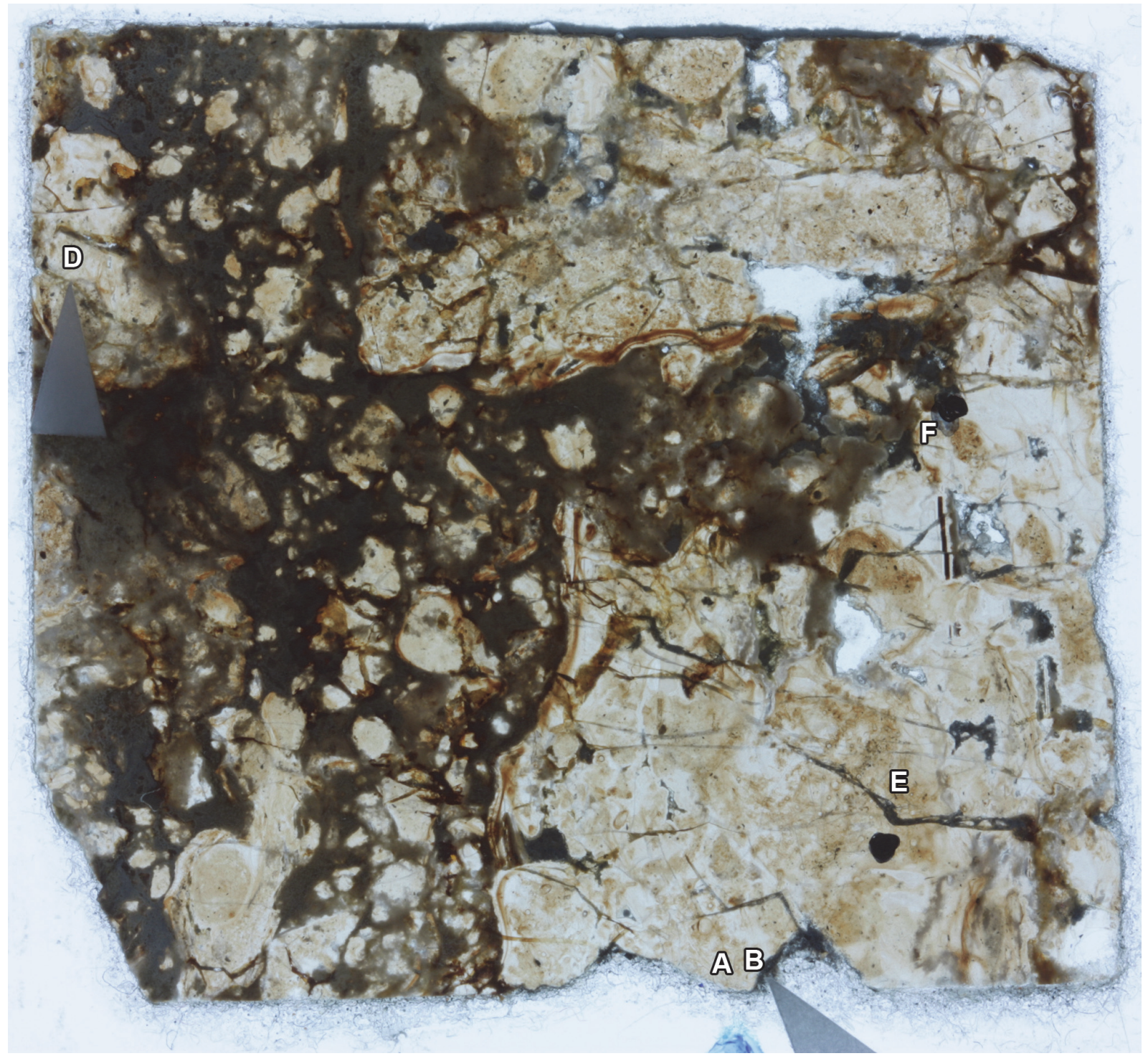




\section{APPENDIX 4.}

Overview of specimens on thin section AUGD 12447.

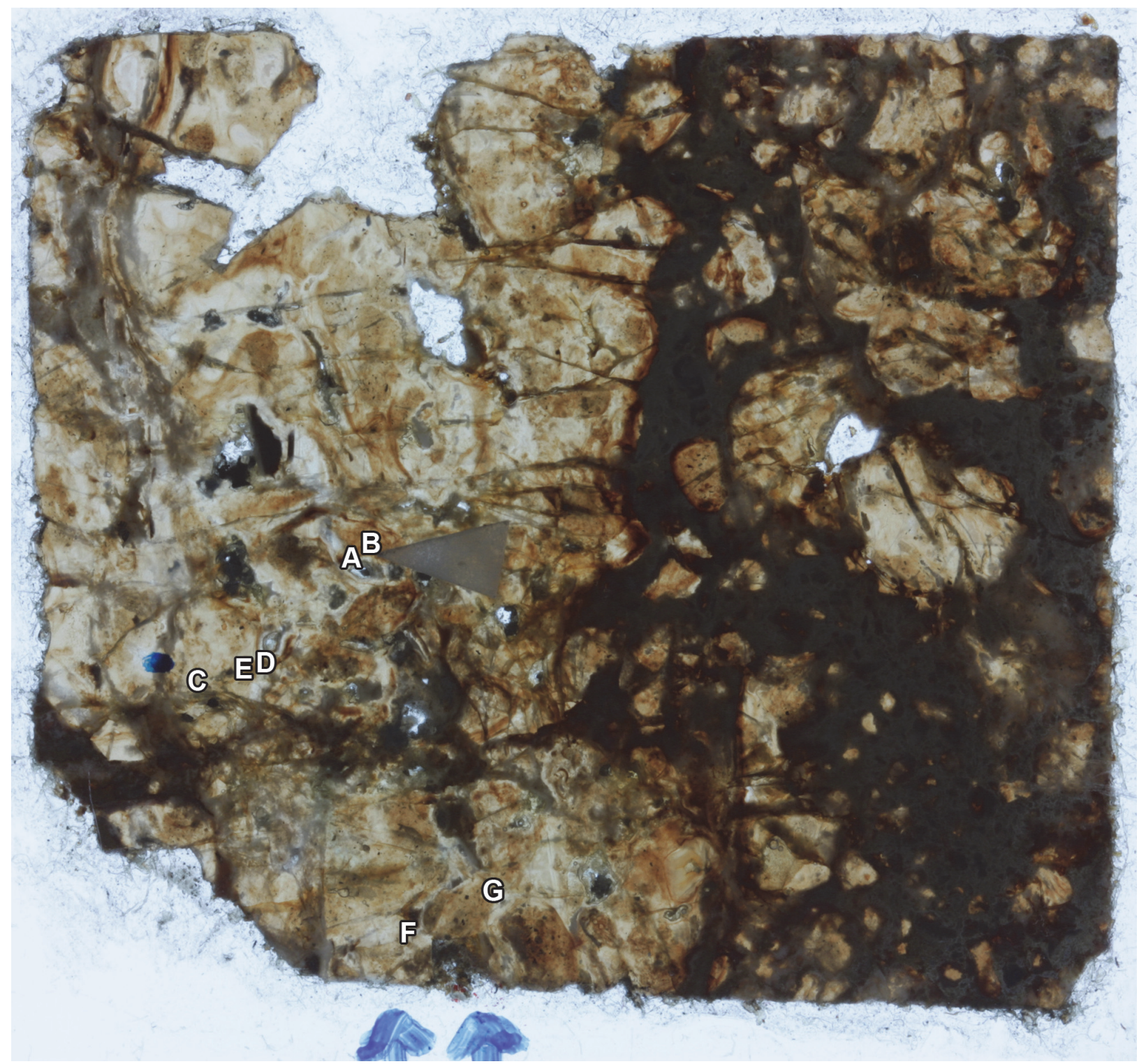




\section{APPENDIX 5.}

Overview of specimens on thin section AUGD 12448.

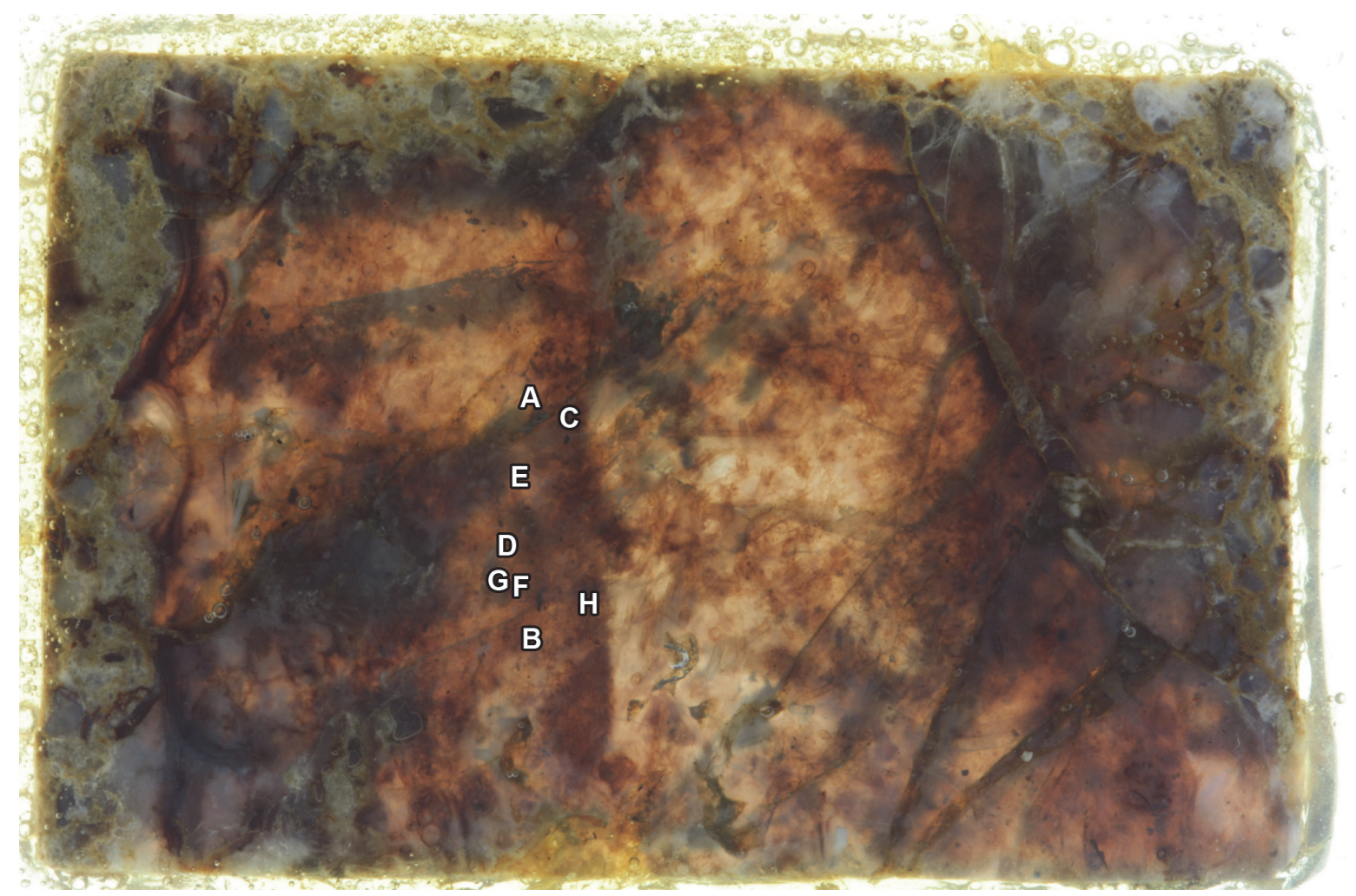




\section{APPENDIX 6.}

Overview of specimens on thin section AUGD 12449, not glued side.

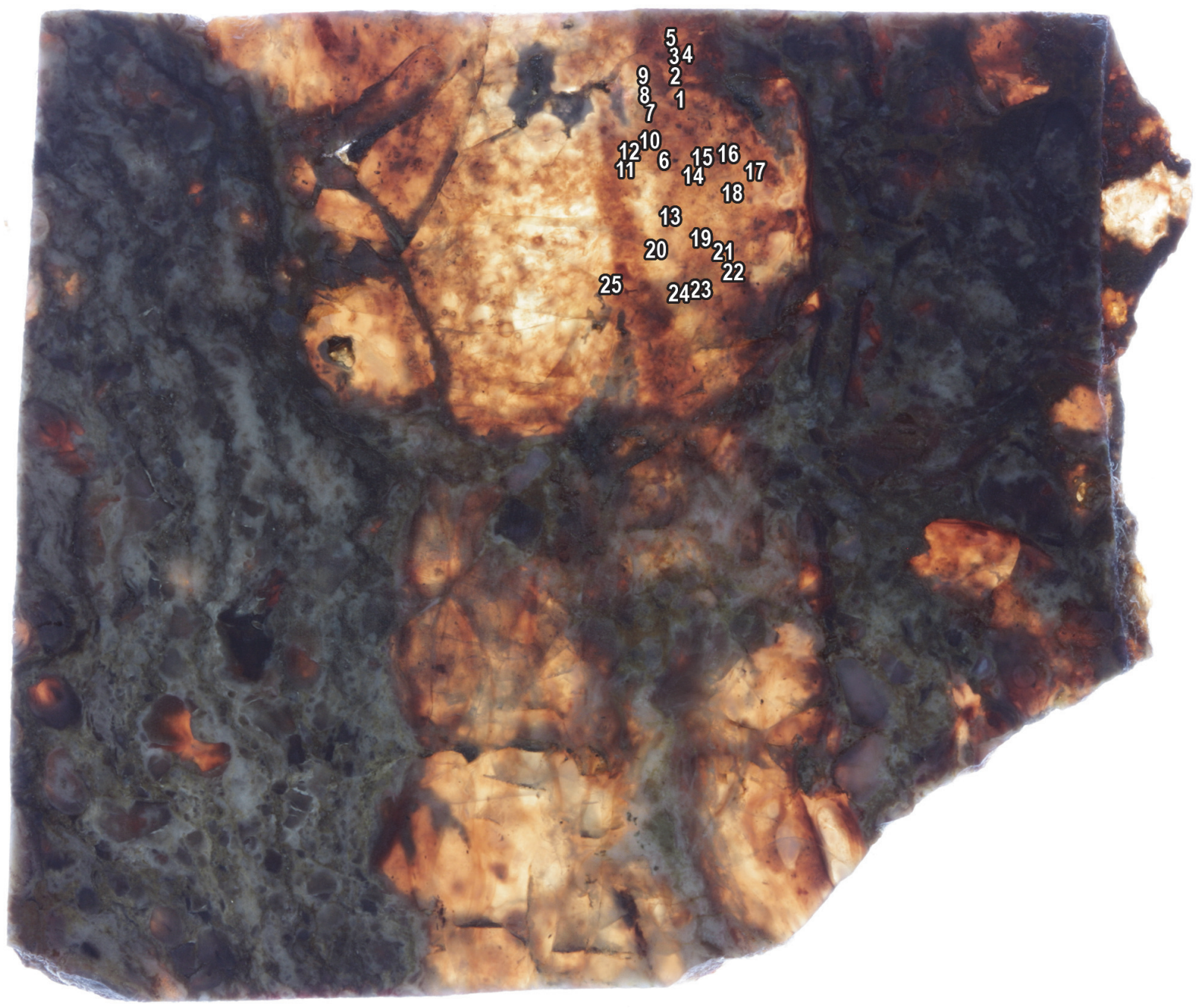




\section{APPENDIX 7.}

Overview of specimens on thin section AUGD 12449, glued side.

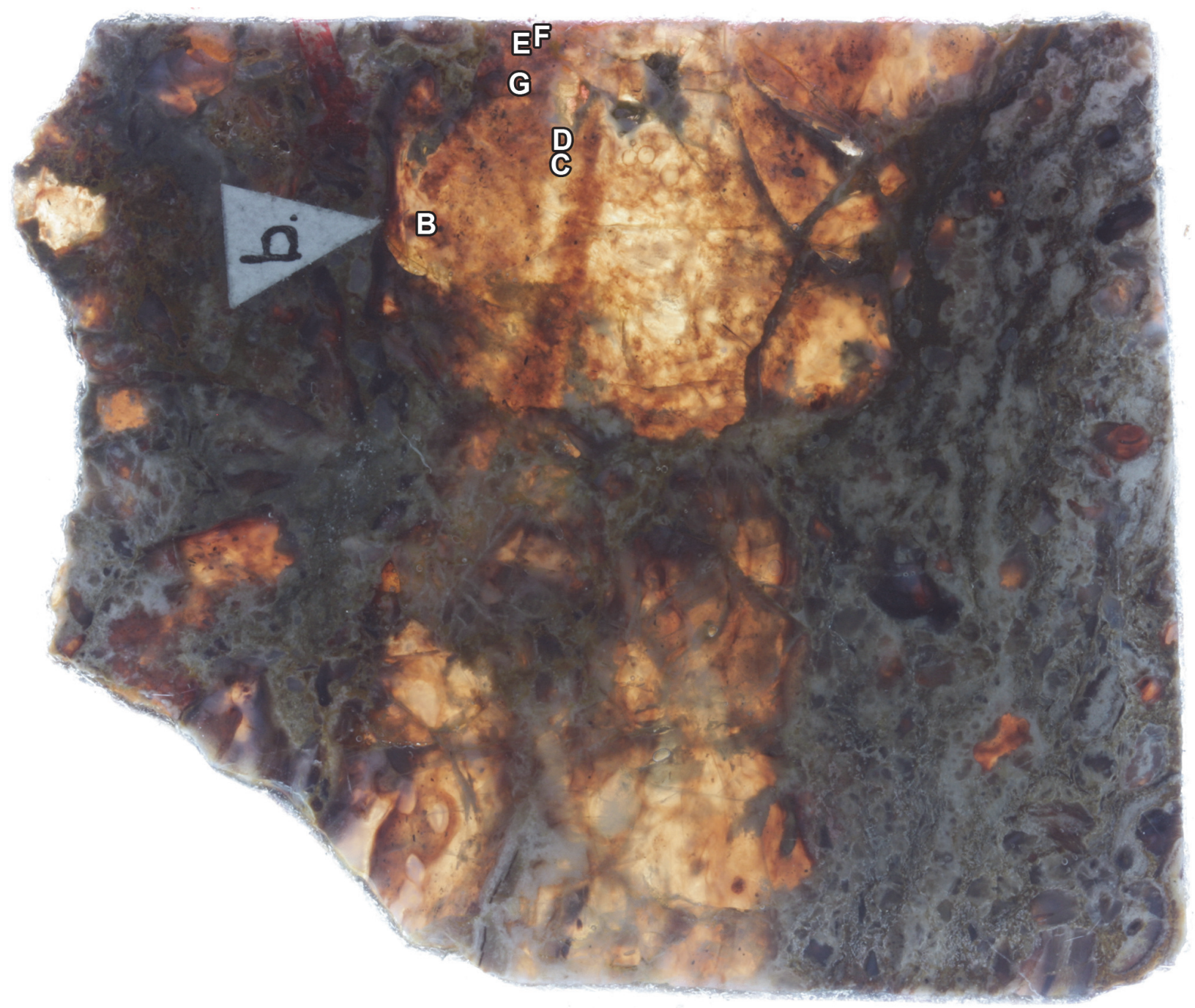




\section{APPENDIX 8.}

Overview of specimens on thin section AUGD 12451.

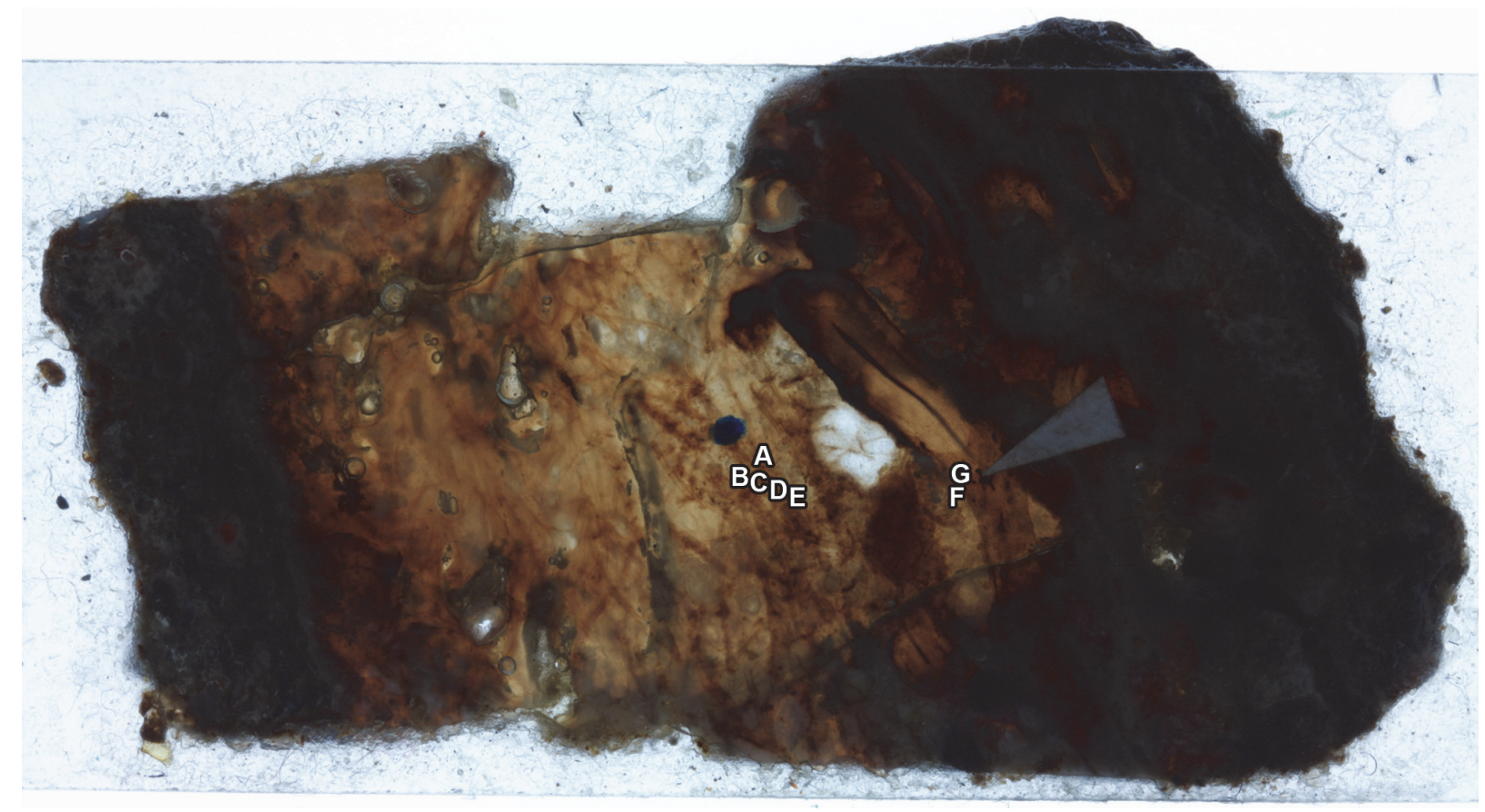




\section{APPENDIX 9}

Overview of specimens on thin section AUGD 12452.

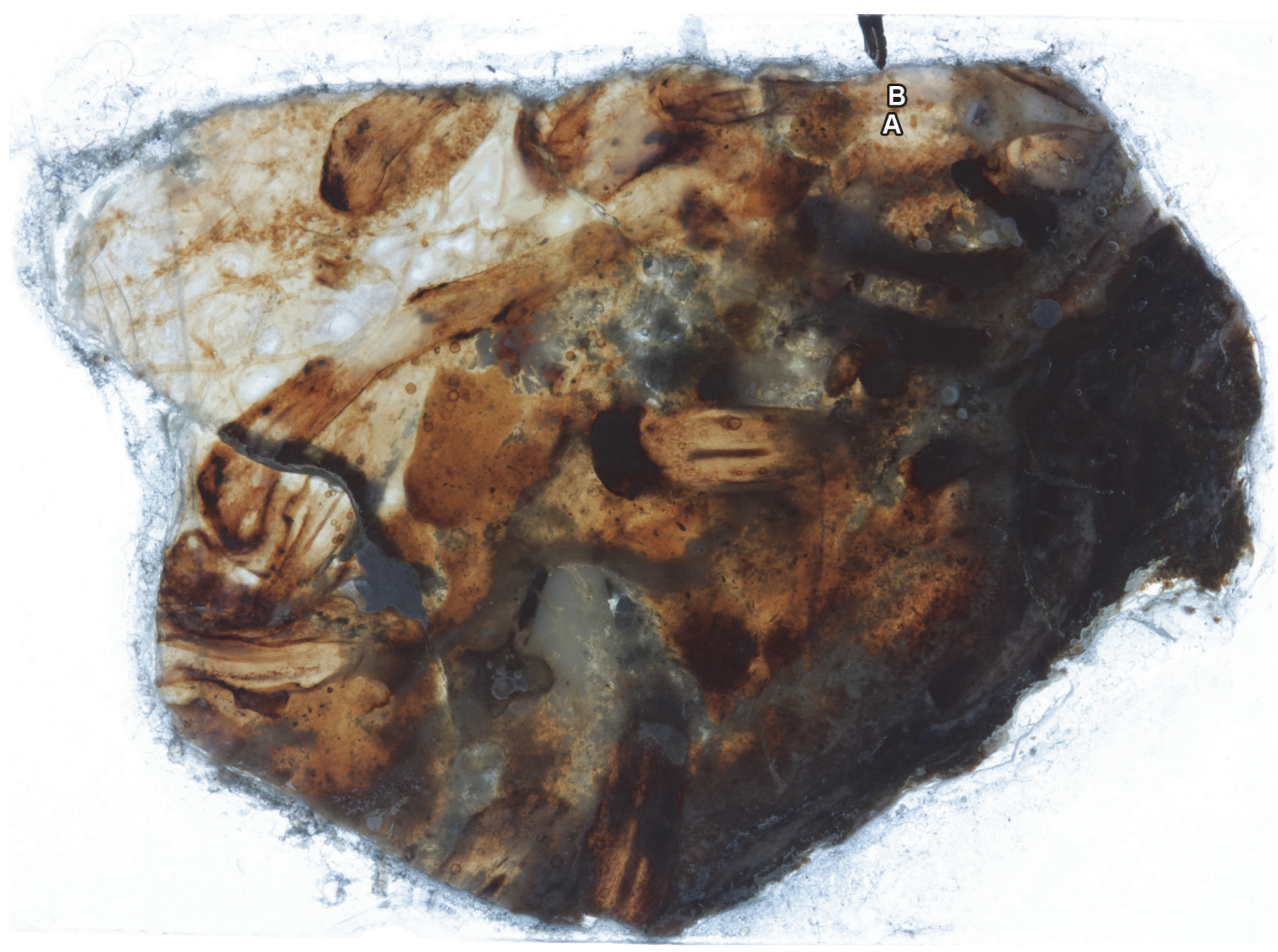


APPENDIX 10.

Overview of specimens on thin section AUGD 12454.

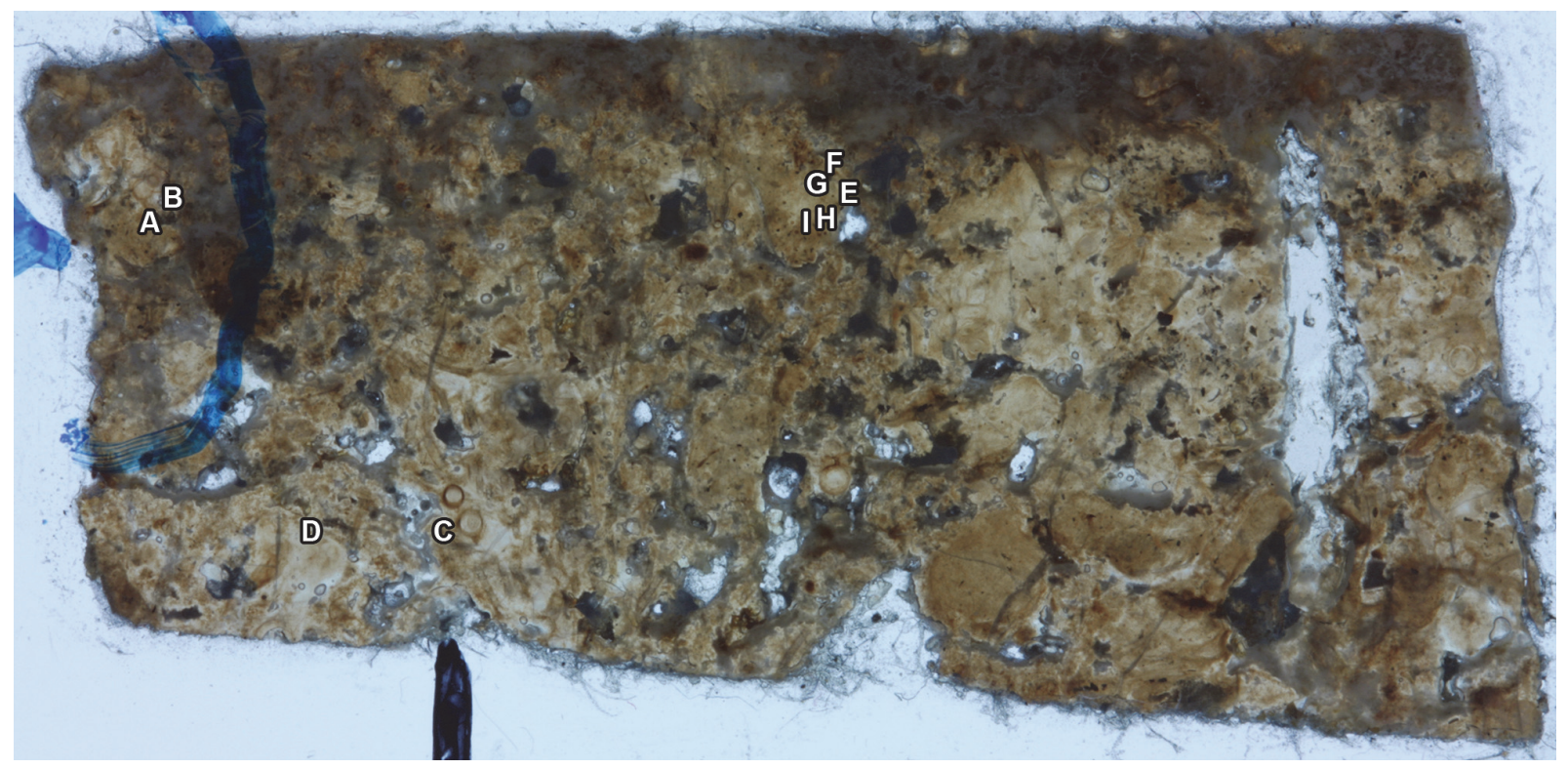

